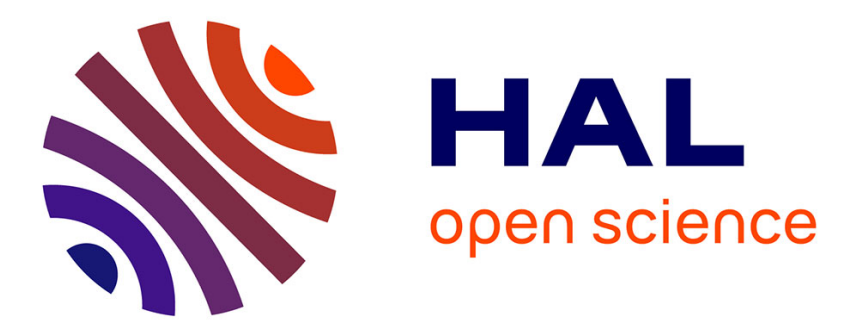

\title{
Erosion under climate and human pressures: An alpine lake sediment perspective
}

Fabien Arnaud, Jérôme Poulenard, Charline Giguet-Covex, Bruno Wilhelm, Sidonie Révillon, Jean-Philippe Jenny, Marie Revel, Dirk Enters, Manon Bajard, Laurent Fouinat, et al.

\section{To cite this version:}

Fabien Arnaud, Jérôme Poulenard, Charline Giguet-Covex, Bruno Wilhelm, Sidonie Révillon, et al.. Erosion under climate and human pressures: An alpine lake sediment perspective. Quaternary Science Reviews, 2016, 152, pp.1 - 18. 10.1016/j.quascirev.2016.09.018 . insu-01375648

\section{HAL Id: insu-01375648 https://hal-insu.archives-ouvertes.fr/insu-01375648}

Submitted on 19 Jan 2017

HAL is a multi-disciplinary open access archive for the deposit and dissemination of scientific research documents, whether they are published or not. The documents may come from teaching and research institutions in France or abroad, or from public or private research centers.
L'archive ouverte pluridisciplinaire HAL, est destinée au dépôt et à la diffusion de documents scientifiques de niveau recherche, publiés ou non, émanant des établissements d'enseignement et de recherche français ou étrangers, des laboratoires publics ou privés. 
Invited review

\title{
Erosion under climate and human pressures: An alpine lake sediment perspective
}

\author{
Fabien Arnaud a, *, Jérôme Poulenard a , Charline Giguet-Covex ${ }^{\mathrm{a}, \mathrm{b}}$, Bruno Wilhelm c, \\ Sidonie Révillon ${ }^{\mathrm{d}}$, Jean-Philippe Jenny ${ }^{\mathrm{e}}$, Marie Revel ${ }^{\mathrm{f}}$, Dirk Enters ${ }^{\mathrm{g}}$, Manon Bajard ${ }^{\mathrm{a}}$, \\ Laurent Fouinat ${ }^{\mathrm{a}}$, Elise Doyen ${ }^{\mathrm{h}}$, Anaëlle Simonneau ${ }^{\mathrm{i}}$, Cécile Pignol ${ }^{\mathrm{a}}$, \\ Emmanuel Chapron ${ }^{\mathrm{i}, \mathrm{j}}$, Boris Vannière ${ }^{\mathrm{k}}$, Pierre Sabatier ${ }^{\mathrm{a}}$ \\ ${ }^{a}$ Environment Dynamics and Territories of Mountains (EDYTEM), Université Savoie Mont Blanc, CNRS, 73000 Chambéry, France \\ b BioArCh, Department of Archaeology, University of York, York, United Kingdom \\ ${ }^{\mathrm{c}}$ LTHE, University Grenoble Alpes, CNRS, IRD, 38000 Grenoble, France \\ ' SEDISOR/UMR6538 “Domaines Océaniques”, IUEM, 29000 Plouzané, France \\ e Centre Eau Terre Environnement, Institut National de la Recherche Scientifique (INRS), G1K9A9 Québec Qc, Canada \\ ${ }^{\mathrm{f}}$ Géoazur, Université de Nice Sophia antipolis, CNRS, IRD, OCA, 06000 Nice, France \\ ${ }^{\mathrm{g}}$ Niedersächsisches Institut für historische Küstenforschung, 26382 Wilhelmshaven, Germany \\ h INRAP, 51520 Saint-Martin sur-le-Pré, France \\ ${ }^{\mathrm{i}}$ ISTO, université d'Orléans, CNRS, BRGM, F-45000 Orléans, France \\ j GEODE Université Toulouse Jean Jaurès, CNRS 31000 Toulouse, France \\ ${ }^{\mathrm{k}}$ Chrono-environnement, CNRS, Université de Franche-Comté, 25000 Besançon, France
}

\section{A R T I C L E I N F O}

\section{Article history:}

Received 9 May 2016

Received in revised form

15 September 2016

Accepted 21 September 2016

\section{Keywords:}

Erosion

Holocene

Lake sediment

Paleohydrology

Flood

Glacier

Land-use

Anthropocene

\begin{abstract}
A B S T R A C T
We review the scientific efforts over the last decades to reconstruct erosion from continuous alpine lake sediment records. We focused both on methodological issues, showing the growing importance of nondestructive high resolution approaches (XRF core-scanner) as well as progresses in the understanding of processes leading to the creation of an "erosion signal" in lakes. We distinguish "continuous records" from "event-records". Both provide complementary information but need to be studied with different approaches. Continuous regionally-relevant records proved to be particularly pertinent to document regional erosion patterns throughout the Holocene, in particular applying the source to sink approach. Event-based approaches demonstrated and took advantage of the strong non-linearity of sediment transport in high altitude catchment areas. This led to flood frequency and intensity reconstructions, highlighting the influence of climate change upon flood dynamics in the mountain.

The combination of different record types, both in terms of location (high vs. low elevation), sedimentology (high vs. low terrigenous contribution) and significance (local vs. regional) is one of the main outputs of this paper. It allows the establishment of comprehensive histories of NW French Alps erosion, but also and consequently, soil dynamics and hydrological patterns throughout the Holocene. We also discuss the influence of glacier dynamics, one of the major agents of erosion in the Alps.

A major feature is the growing human influence upon erosion at a local scale since at least the middle of the Bronze Age (3500 cal. BP). However and according to the regional record from Lake Bourget, only few periods of rising erosion at local scales generated a regional record that can be discriminated from wetter climatic periods. Among them, the period between 200 BCE and 400 AD appeared to be marked by a generalised rise in human-triggered erosion at local scales in the northern French Alps.

This review highlights the importance of modern high-resolution and interdisciplinary studies of lake sediments, in order to better understand the complex relationships between humans, climate and the Earth system in general. We strongly argue that regional integration of data is now required to move a step further. Such an integration is easier with cost- and time-effective methods as well as after a better definition of approaches and their limits. This should lead to a stronger collaboration between paleo-data producers and modellers in the near future.
\end{abstract}

๑) 2016 Elsevier Ltd. All rights reserved.

\footnotetext{
* Corresponding author.

E-mail address: fabien.arnaud@univ-smb.fr (F. Arnaud).
} 


\section{Introduction}

Erosion processes dynamically link the lithosphere, the atmosphere, the hydrosphere and to some extent the biosphere and the sociosphere. They are thus involved in most processes affecting the "Earth critical zone". In this paper we aim at showing how a regional scale study of alpine lake sediments allowed reconstructing the evolution of different erosion processes throughout the Holocene. Our aim is both to detail and discuss the methods and to synthetize the results obtained from a variety of geologic records that were studied over the last 15 years. We finally propose new perspectives upon both climate and human histories over the last millennia and show perspectives to pursue the effort toward a better knowledge of erosion dynamics throughout the Anthropocene.

Erosion is a generic term used to describe a set of processes leading to the dismantling of the most elevated parts of Earth's surface (sources) while lower parts (sinks) are mantled by erosion products. Erosion comprises i) surface processes, that prepare the dismantling of rocks - i.e. physical and/or chemical weathering ii) grabbing processes by carrying fluids - mostly running water and wind - iii) transport processes by those fluids and iv) the accumulation of solid or dissolved matter into a sink. Erosion should be defined as an ensemble of Earth surface processes that transfer matter from a source to a - more or less remote - sink (Fig. 1). Floods for instance, generate erosion through their grabbing effect. But in return the nature and intensity of weathering processes modulate their solid load and thus how much they are hazardous. Vegetation cover is also an important component modulating Earth critical zone processes. On the one hand, it favours the formation of weathered rock surfaces that are easier to erode than non-weathered rocks, but on the other hand roots and aerial vegetation act as a physical protection of soils against erosion. The flux of matter from sources to sinks thus depends primarily on climate, pedogenesis and vegetation. The two latter forcing factors have been affected for millennia by human activities (Dearing and Jones, 2003; Pope and van Andel, 1984). However, the recent and worldwide spread of human control on Earth surface processes, including urban soil sealing, intensive river damming or large scale water management, completely overpasses natural processes in many regions of the world (Syvitski, 2005; Syvitski and Kettner, 2011), including the European Alps (Jenny et al., 2014). Our study includes the last century together with longer time-scales.
However, we focused on longest time-scales aiming at replacing Earth-climate-human interactions into a long-term perspective. This is indeed required to understand the processes underlying the Anthropocene (Costanza et al., 2007; Dearing et al., 2010).

Because it affects pedogenesis, soil dynamics and vegetation, human land-use is an important forcing factor of erosion. Moreover, growing intensity of water management throughout the last centuries completely modified the erosion budget on a worldwide scale (Skalak et al., 2013; Syvitski, 2005). Indeed, the growing impact of human practices on erosion is one of the main manifestations of the Anthropocene (Brown et al., 2013; Poirier et al., 2011; Syvitski and Kettner, 2011) that is defined as the period when humans became a planet-wide geological factor (Zalasiewicz et al., 2011). However, whereas the concept of the Anthropocene is very young (Crutzen, 2002), the complex interplay between humans and erosion is well-known for millennia. As early as the IVth century BC, the Antique Greek philosopher Plato reported in his dialogue Critias, the threats due to erosion in terms of fertile soil loss (Jowett, 1892). Indeed, it is in the Mediterranean realm and in connection with archaeological studies, that modern science addressed the question of human-erosion relationships through millennia (van Andel et al., 1990). First studies were based on the compilation of outcrop observations which were related to population assessments based on archaeological discoveries (Pope and van Andel, 1984). This participated in the idea that humans became, as early as in the Bronze Age, a major geological agent, at least at local to regional scales. Such an approach is still very viable, in particular in regions like Greece, where erosion processes challenge the current societal development and where archaeological legacy is important (e.g. Butzer, 2005; Lespez, 2003). However, this does not permit to reconstruct processes and triggering factors both continuously and along a common chronological framework. Recent studies of modern-time erosion took advantage of the sediment cascade concept to understand and model erosion fluxes (Burt and Allison, 2010). However, at our knowledge no studies yet transposed it to paleo records. There is also an abundant literature aiming at describing and quantifying current erosion processes in the Alps, especially from debris flows (e.g. Berger et al., 2011) and colluvial fans (e.g. Hornung et al., 2010) analysis. However, to quantify the current erosion in mountain areas remains challenging (Konz et al., 2012).

Lake sediment can be used to bridge the gap between past discontinuous records and the study of modern erosion dynamics.

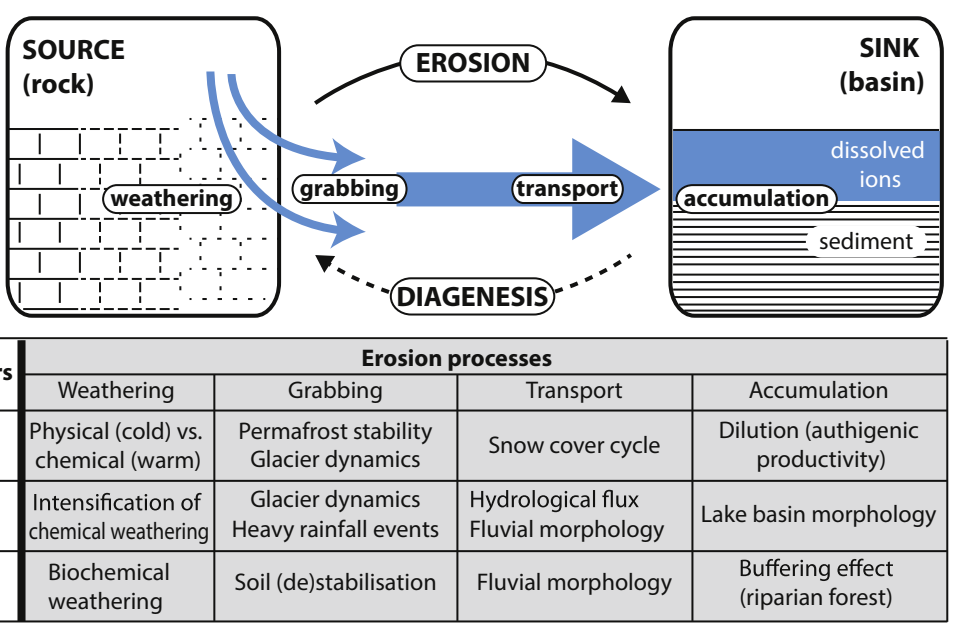

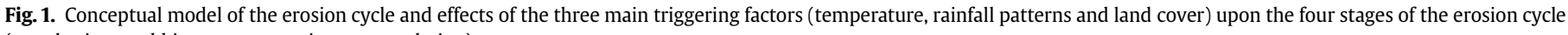
(weathering, grabbing, transportation, accumulation). 
Indeed, they contain both remains of past land-use (pollen, macroremains, non-pollen palynomorphs, DNA etc.) and the terrigenous fraction brought by erosion from the catchment area to the lake bottom. Such an approach was developed in the late 1980's by a group of pioneers, in particular Frank Oldfield and John Dearing, who applied it with success both in Papua New Guinea (Oldfield et al., 1980) and Northern Europe (Dearing, 1983; Dearing et al., 1987; Foster et al., 1985). Since then, growing questions about Holocene climate fluctuations boosted the interest for Holocene sediment sequences. In particular, abundant literature was dedicated to the search for the link between terrigenous fluxes and precipitation patterns. The onset of high resolution, nondestructive and cost effective investigation tools based on rock magnetic, physical and geochemical sediment properties marked the early 2000's participating in the increasing amount of studied sequences and a better definition of Holocene hydroclimate variability (Arnaud et al., 2005; Bertrand et al., 2007; Chapron et al., 2002; Haug, 2001). However, in areas where human activities deeply shaped the environment for millennia it appeared more and more obvious that reconstructing climate from erosion cannot be successful without understanding the influence of human practices and inversely (Arnaud et al., 2005; Dearing and Jones, 2003; Foster et al., 2003; Giguet-Covex et al., 2014, 2012; Jones et al., 2013). As a consequence, climate and land-use changes as well as their impacts upon the erosion cycle must be understood together in order to be able to reconstruct each of them accurately.

\section{Material and methods}

\subsection{Studied records and erosion proxies}

This paper aims at reviewing studies on erosion-related topics using lake sediments in the Alps. It is mainly based upon the results from nine sediment sequences taken from 8 lakes in the French Alps (supplementary material Table S1; Fig. 2). Most of those sequences -6 over 8 - span at least the last 7000 years and are spread from $230 \mathrm{~m}$ up to $2300 \mathrm{~m}$ asl (Table S1). A special focus was brought to the upper River Rhône catchment area (Fig. 2), from which 7 sediment records were studied. They were taken from 6 lakes covering an altitudinal gradient of $2000 \mathrm{~m}$, considering their own altitude and $4500 \mathrm{~m}$, considering the altitude of their catchment areas (Table $\mathrm{S} 1$ ). It was hence possible to compare results on a regional basis in a common chronological, climatic and cultural framework. All selected sequences present a well-studied signal of terrigenous input and most of them -7 over 9 - were also studied through environmental proxies such as pollen, charcoal, biomarker and/or sediment DNA. All those sequences were previously published along with a detailed age-depth model with age uncertainty less than \pm 100 years.

Twenty-one other lake sediment records of terrigenous discharge were considered in the present review (Table S1). They were mostly studied to document flood-triggered deposits or glacier dynamics (Fig. 2). Ten of them were stacked into a Northern and five in a Southern Alps flood activity curve by Wirth et al. (2013; Fig. 2).

As matter of comparison we included reconstructions of Rhône floodplain hydro-sedimentary dynamics in the vicinity of Lake Bourget (Salvador and Berger, 2014, Fig. 2). We also integrated paleohydrological records independent of erosion dynamics: the lake level record from Lake Cerin (Magny et al., 2011) in the Jura Mountain and the two longest and most complete tree-ring-based reconstructions of Holocene glacier fluctuations in the Alps (Fig. 2) from glaciers Aletsch (Holzhauser et al., 2005) and Mer de Glace (Leroy, 2012).

Regarding lake sediment records we divided the studied sequences into "continuous" and "event-based", depending on the nature of erosion signals (Table S1). In general, this distinction fits with an altitudinal gradient: low elevation lakes often yield continuous sediment records whereas high altitude lakes provide event-based records.

\subsection{Low elevation lakes: continuous erosion records}

In low elevation lakes, the sediment is a mixture of autochthonous and allochthonous particles. This is typically the case of low altitude hard water lakes fed by streams or rivers. Making the assumption that the autochthonous flux varies far less than the terrigenous - which was recently demonstrated in the case of Lake Bourget (Arnaud and Révillon, 2015) - it is possible to use a high resolution proxy for the terrigenous fraction as a proxy of terrigenous flux (Arnaud et al., 2005; Bertrand et al., 2007; Wessels, 1998), as commonly done in paleoceanography (Bloemendal and deMenocal, 1989; Chapman and Shackleton, 1998; Haug, 2001). This was done in low elevation lakes Bourget (Arnaud et al., 2012, 2005; Debret et al., 2010), Moras (Doyen et al., 2013), Paladru (Simonneau et al., 2013b) and La Thuile (Bajard et al., 2015), all located in the Northern French Alpine Foreland, as well as in Lake Constance in the course of the River Rhine (Wessels, 1998).

An important parameter in interpreting continuous erosion records is the size of the lake catchment area. In our case records can be divided into two types: small lakes with restricted catchment areas $\left(<10 \mathrm{~km}^{2}\right)$ providing local information and large lakes with a large catchment area $\left(>4000 \mathrm{~km}^{2}\right)$ yielding regional information. Both records are highly complementary. Indeed, we assume that local records provide details of various human practices and ecological dynamics (such as soil and vegetation developments) which are highly dependent on local parameters: altitude, lithology as well as cultural, technological and economic factors. On the contrary, we assume regional records are less affected by local human disturbances and are representative of the regional evolution of erosional patterns including climatic changes. Verifying those assumptions was one of the underlying purposes of our research over the last 10 years.

Numerous publications are presenting several thousand yearslong continuous erosion records from low altitude alpine lakes with small-scale $\left(<100 \mathrm{~km}^{2}\right)$ catchment areas (Bajard et al., 2015; Cruise et al., 2009; Czymzik et al., 2013; Dearing et al., 2001; Doyen et al., 2013; Foster et al., 2003; Joannin et al., 2014; Jones et al., 2013; Lauterbach et al., 2012; Manalt et al., 2001; Noël et al., 2001; Simonneau et al., 2013b; Swierczynski et al., 2013). In those cases, the terrigenous flux or at least the more commonly and more accurately-measured relative terrigenous contribution to the sediment can be obtained. XRF core-scanners bring a valuable improvement of such an approach, allowing reconstruction of geochemical anomalies linked to the input of terrigenous particles at high resolution (Bertrand et al., 2007; Doyen et al., 2016, 2013; Haug, 2001; Simonneau et al., 2013b). To go a step further it is also possible to reconstruct erosion patterns through weathering indexes based on the assumption that minerals (alumina-silicates) preferentially loose certain cations, such as potassium $(\mathrm{K})$ or sodium $(\mathrm{Na})$ vs. silicon $(\mathrm{Si})$ or aluminium $(\mathrm{Al})$ during weathering processes. Traditionally, this can be tracked using the chemical index of alteration (CIA) (Nesbitt and Young, 1982). However, because Na cannot be measured by XRF core-scanners and $\mathrm{Al}$ is often close to the limit of detection, we proposed the $\mathrm{K} / \mathrm{Ti}$ ratio as a high resolution proxy of chemical weathering (Arnaud et al., 2012). Such an approach was adopted for lakes Moras (Doyen et al., 2013) and La Thuile (Bajard et al., 2015; Doyen et al., 2013). This can be completed by organic matter provenance proxies as it was performed for Lake Paladru (Simonneau et al., 2013b). 


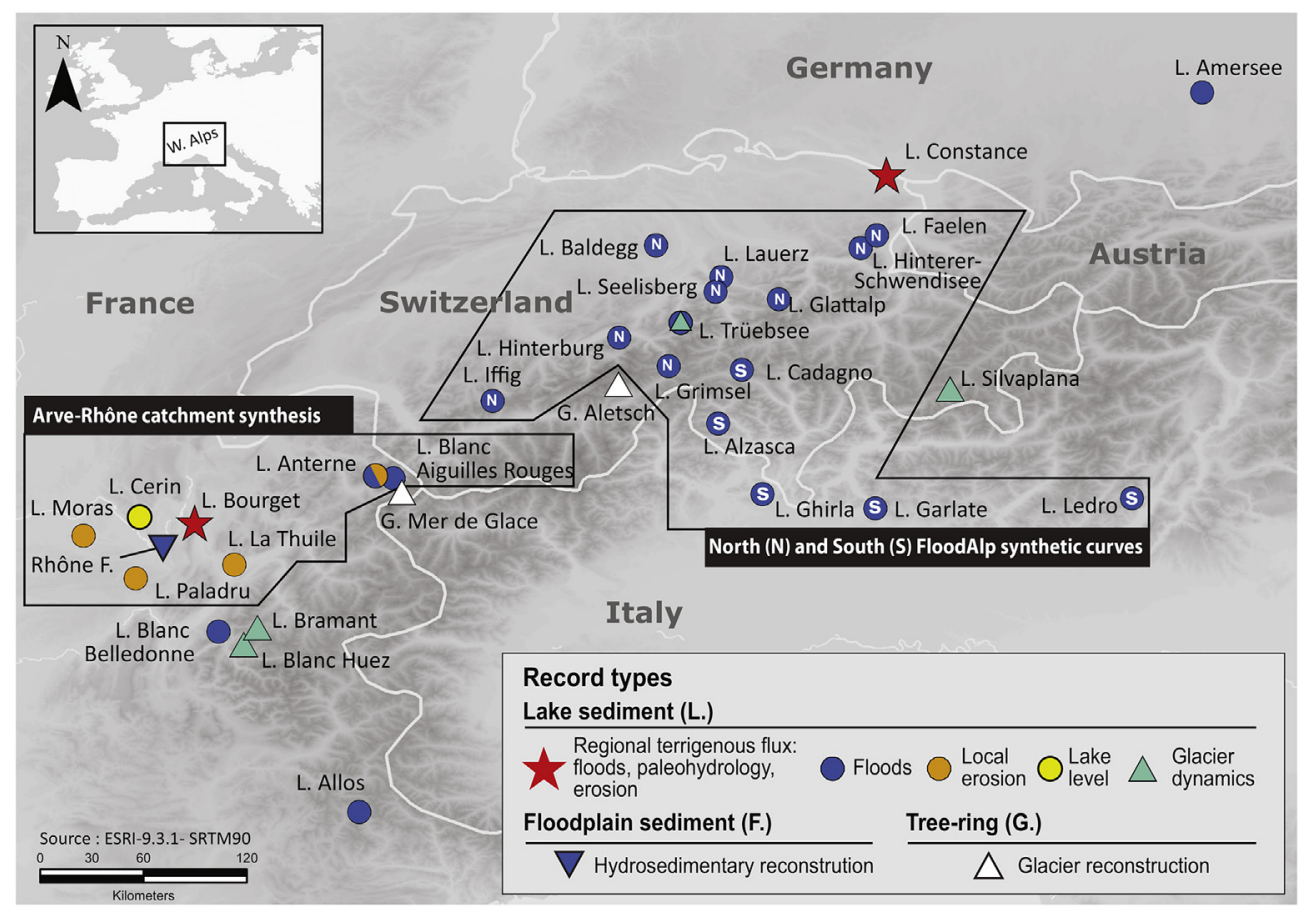

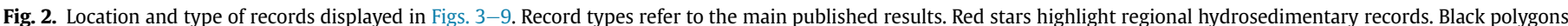

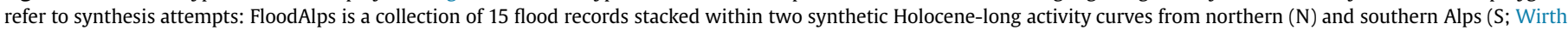
et al., 2013b); the Arve-Rhône catchment synthesis is exposed in the present article. Related references are shown in Table S1.

When compared to "small lake" studies, there are very few publications of large lake erosion records of regional significance. In the alpine realm, this was only the case for the few papers dedicated to long cores taken from Lake Constance in the 1990s' (Wessels, 1998) as well as for the long cores from Lake Bourget we took in 2000 (Chapron et al., 2005), 2001 (Arnaud et al., 2005; Chapron et al., 2005) and 2004 (Arnaud et al., 2012; Debret et al., 2010). Indeed, from our knowledge no Holocene large-scale basin erosion records were ever published from lakes Geneva, Zurich, Garda, Como or Iseo, to speak only about the largest, deepest and most studied ones. Those lakes were on the other hand intensively studied through geophysical (seismic) investigations revealing active depocenters filled by several tens of meters of Holocene sediments brought by some of the main rivers draining the Alps as well as giant mass-wasting deposits (Baster et al., 2003; Fanetti et al., 2008; Finckh et al., 1984; Fiore et al., 2011; Girardclos et al., 2005; Hsu and Kelts, 1970). When sediment cores spanning the whole Holocene were retrieved from coring sites that were not directly exposed to deposition of the main rivers, studied proxies were in general not related to erosion (Anadón et al., 2006) or not representative of the whole lake catchment area (Girardclos et al., 2005; Lauterbach et al., 2012; Lister et al., 1983; Moscariello et al., 1998). One can only regret this state of research, especially since we know that perialpine lakes are one of the world hotspots in the 1970's where fundamental limnogeology (Hsü and Kelts, 1984) and sedimentology (Hsü, 1989) concepts and investigation tools were designed and tested.

Back to our aim of reconstructing alpine erosion under climate and human pressures in the Alps, those records are potentially highly valuable because they are widely representative. As a matter of fact, the few related studies are currently among the most cited paleohydrological publications from the Alps. There are many other well-suited lakes around the Alps for such studies. However, until now technical limitations precluded them to be cored due to an excessive water depth and high Holocene sediment accumulation.
Indeed, to recover such sequences heavy drilling equipment is required which often is beyond the funding capacities of standard research programs. Lake Bourget is probably the perialpine lake from which the longest and most studied sediment sequences were recovered (Arnaud et al., 2012, 2005; Chapron et al., 2005; Debret et al., 2010; Jacob et al., 2009, 2008a, 2008b; Magny et al., 2012). Noteworthy is the major research effort in the late 1990's: drilling of Lake Annecy, which generated a large number of papers collected in a 2001 special issue of the Journal of Paleolimnology (Oldfield and Berthier, 2001). However, regarding erosion patterns, Lake Annecy represents a slightly smaller catchment area which does not permit to integrate erosion at a regional scale whereas it developed to be a major site to discuss erosion processes (Dearing et al., 2001; Foster et al., 2003; Jones et al., 2013).

While they were taken in different parts of Lake Bourget, cores LDB01-I and LDB04-I yielded very similar geochemical records (Arnaud et al., 2012). We used those signals as unique windows into regional erosion patterns along the course of the Rhône River, one of the four major rivers draining the Alps. At Lake Bourget, the socalled French Upper Rhône drains about $4000 \mathrm{~km}^{2}$. The Swiss part of the Rhône catchment is here neglected as all sediment eroded upstream is supposed to be trapped in Lake Léman. In such a large mountain area the geologic diversity of potential erosion sources allows to distinguish crystalline massifs (i.e. Mont Blanc and Aiguilles Rouges) from prealpine sedimentary and low grade metamorphic rocks (Revel-Rolland et al., 2005). Moreover, the huge vertical gradient of more than $4500 \mathrm{~m}$, from Lake Bourget $(230 \mathrm{~m}$ asl) to the summit of Mont Blanc ( $4808 \mathrm{~m}$ asl) results in a large diversity of soil weathering that also can be tracked through the composition of the terrigenous fraction. We coupled low resolution methods with high levels of explanation (Nd isotopes; element geochemistry) and high resolution XRF core-scanner data (K/Ti ratios) to follow the evolution of weathering patterns and physical erosion patterns within the whole catchment area.

We took advantage of the specific setting at Lake Bourget to 
develop a source to sink approach illustrated in Fig. 3. This highlights mineralogical markers (CIA and $\mathrm{K} / \mathrm{Ti}$ ) vary both with provenance source (i.e. crystalline massif $v s$. sedimentary and metamorphic ones) and altitude (degree of soil weathering). On the contrary, $\varepsilon N d$ varies only with provenance without being affected by weathering processes. This is particularly interesting as all glaciated areas are located in a small part of the catchment area that is largely dominated by crystalline rocks, i.e. with $\varepsilon \mathrm{Nd}<-5$. We then postulated that human activities did not spread with the same intensity at different altitudes. The extreme illustration of it is the obvious absence of agro-pastoral activities on high altitude glaciated areas. Accordingly, one knows that pastures can be located at higher elevation than crops. Taking account those facts, we were able to discuss forcing factors of erosion fluxes throughout the Holocene.

Moreover, fluvial dynamics of the River Rhône were intensively studied throughout the Late Glacial and the Holocene in the vicinity of Lake Bourget. In particular a recent synthesis of the evolution of the so-called Basses Terres area (Salvador and Berger, 2014), just downstream Lake Bourget, provides a totally independent erosion record that complements the one of Lake Bourget.

Coupling the Lake Bourget regional signal with local records of smaller lakes as well as independent records of fluvial dynamics will allow us to discuss the history of erosion at various spatial scales.

\subsection{Records of high elevation erosion-events}

In mountain areas, lake sedimentology depends highly on the catchment-lake relationship. Indeed when the catchment area is large compared to the lake surface area and is made of easily erodible material such as periglacial tills and moraines or shales, the existence of vertical gradients combined with the occurrence of heavy rainfall events can lead to very high sedimentation rates sustained by erosion processes (including glacier erosion, rock breaking by frost action, overgrazing, heavy rainfall grabbing and extreme stream transport). This leads often to average sedimentation rates between 2 and $5 \mathrm{~mm} / \mathrm{a}$ (Giguet-Covex et al., 2011; Wilhelm et al., 2013, 2012b). On the opposite, lakes with restricted catchment areas represent very low sedimentation rates (Anderson et al., 2011; Ilyashuk et al., 2011), typically around $100 \mu \mathrm{m} / \mathrm{a}$, due to the absence of significant terrigenous input and low primary productivity leading to very low production of autochtonous components (mainly organic matter and biogenic opal). This last type of lakes is not well-suited to reconstruct past erosion patterns. In some cases, however, exceptional periods of soil destabilisation can be recorded highlighting major environmental shifts (Brisset et al., 2013). This remains exceptional and most of our high elevation records are related to lake systems with a sedimentology dominated by terrigenous input (lakes Anterne, Allos, Blanc Aiguilles Rouges, Blanc Belledonne).

In Europe, most mountain stream systems are torrential, which means water discharge is highly sporadic with alternating long periods of low waters and some rare and short episodes of flash floods that can be devastating. As a consequence the sediment accumulation in high altitude terrigenous lake systems is characterised by elevated and highly variable sedimentation rates. Accumulation is a succession of complex flood deposits of varying thickness and grainsize. In such cases, establishing age-models is challenging as the sedimentology is complex and submitted to various disturbances. Among them, earthquake shaking are particularly problematic as they can generate instantaneous mass wasting deposits which can be misinterpreted as flood deposits (Arnaud et al., 2006, 2002; Doig, 1990; Wilhelm et al., 2016a). Moreover, in such systems the allochthonous fraction largely dominates the sediment composition which precludes the use of geochemical logging as a proxy of average terrigenous input. Reconstructing erosion then requires to multiply radiocarbon dates placed at strategic places in the sequence where acceleration of the sedimentation rate is expected based both on dating and sedimentological features - see for instance Giguet-Covex et al. (2011). Highly detailed sedimentological studies are thus absolutely necessary in order to recognize, document and characterize each flood-borne layer (Arnaud et al., 2002; Giguet-Covex et al., 2012; Wilhelm et al., 2013, 2012a, 2012b).

\subsubsection{Documenting flood-borne deposits}

This approach can only be applied when we are sure that a given deposit was flood-triggered (Nesje et al., 2001; Støren et al., 2010). Indeed, there are several other ways to bring coarse-grained deposits into mountain lakes, including aerial and subaqueous slope failures or avalanches (Wilhelm et al., 2016a,b). Passega proposed a simple bi-plot diagram (Q50 vs. Q90) to distinguish various transport processes within streams and rivers (Passega, 1964). This was based upon the fact that the transport capacity (tracked by Q90 values) of a water flow at a given velocity depends on its density, i.e. its fine particle load (tracked by Q50 values). We adapted Passega's concept to lake sediments in order to distinguish between flood deposits and other coarse-grained deposits. Our basic assumption was that in Passega's diagram, a poorly-loaded water flow will

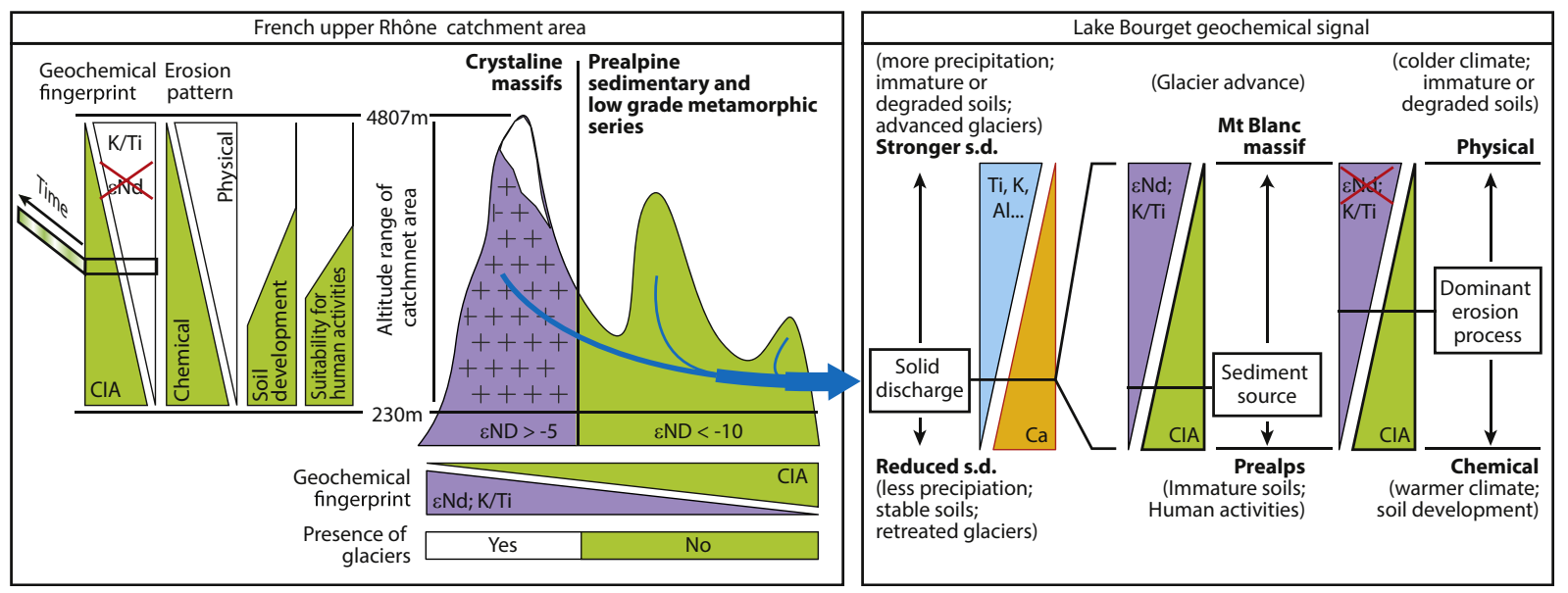

Fig. 3. Schematic representation of the source to sink approach applied to the Arve/Rhône river system (source) and Lake Bourget (sink). 
generate a deposit with grainsize characteristics close to the 1:1 line $(\mathrm{Q} 50=\mathrm{Q} 90)$. On the contrary, a highly sediment-loaded water flow will present a lower Q50, due to the abundance of a finegrained matrix with a relatively higher Q90 due to high transport capacity. Such a deposit can also be distinguished in a sorting vs. asymmetry diagram, in which both parameters will be higher than for flood deposits (Arnaud et al., 2002; Lignier, 2001). This led us to distinguish grain-supported deposits, attributed to floods and matrix-supported deposits, attributed to sediment reworking following slope failures (Arnaud et al., 2002). Noticeably, we observed a direct avalanche deposit only once in all our studied lakes (Wilhelm et al., 2013).

The recognition of flood-triggered layers relies upon the high resolution observation of grain-size parameters from bottom to top in instantaneous deposit, i.e. a sediment layer or a sequence of superimposed layers that is remarkably different from background sedimentation. This is, however, almost impossible to apply on small-scale deposits which are smaller than the typical sampling steps for micrograinsize measurements (in general $5 \mathrm{~mm}$ ). In such cases, we generally apply a site-dependent study based on a set of sediment cores, in order to deduce triggering processes of different layers from their spatial distribution within the lake: Lake Blanc Belledonne (Wilhelm et al., 2012a,b) and Lake Allos (Wilhelm et al., 2015). Indeed, flood deposits should be observed along a transect from the stream inlet to the centre of the lake, whereas deposits resulting from slope failures should come from any part of the lake. Of course slope failure could originate from steep delta slopes, in particular following earthquakes (Arnaud et al., 2006, 2002; Chapron et al., 1999; Doig, 1990; Nomade et al., 2005; Strasser et al., 2013; Wilhelm et al., 2016a). However, from our observations it appears that such deposits are in general thick enough to be studied in detail regarding their grainsize parameters and thus be distinguished from flood deposits as documented for lakes Anterne (Arnaud et al., 2002; Giguet-Covex et al., 2012) and Blanc Aiguilles Rouges (Wilhelm et al., 2013).

To overcome the question of detection and characterisation of small-scale flood deposits, we attempted to use high resolution geochemical logging (Giguet-Covex et al., 2012; Wilhelm et al., 2012a,b, 2013). Such a method is based upon a double observation: i) gravity segregation at the time of deposition of the flood layers leads to a sorting of transported grains from coarse to fine and from bottom to top of a given flood deposit and ii) in most cases this sorting can be tracked by changes in chemical composition of the terrigenous fraction. Fig. 4 displays 3 case studies for which different chemical ratios were used. In all cases geochemical logging allowed to detect the basal coarse layer of flood deposits. We then tried to push the method a step further to assess the intensity of flood events that generated such deposits.

\subsubsection{Flood intensity}

Grainsize and thickness are two of the flood layers characteristics that are generally said to be dependent on flood intensity (Nesje et al., 2001; Wilhelm et al., 2015). Regarding grainsize this is based upon Hjülstrom's pioneer work that empirically linked the behaviour (i.e., erosion, transport or deposition) of a given particle size and a given velocity flow of pure water (Hjulström, 1935). We assumed that the maximum grainsize (Q90max) in a given flood deposit was reflecting the maximum current velocity during the flood event that transported it into the lake basin. In several cases, it was possible to link this parameter with a geochemical element ratio in thick sequences for which it was possible to measure grainsize parameters (Fig. 4). It was then possible to attribute an intensity level to flood deposits that were too small to be measured for grainsize.

We also investigated the relationship between Q90max and the thickness of flood sequences. We showed that in most cases there is a strong relationship between those characteristics (Fig. 5). However, in a given catchment area this relationship can be modified through time by environmental changes, in particular humantriggered disturbances leading to increased erosion rates. We evidenced a shift in grainsize vs. flood layer thickness due to Bronze Age early pasturing activities in Lake Anterne (Giguet-Covex et al., 2011). Interestingly this shift also increased the sensitivity of the catchment area to heavy rainfall-triggered erosion, thus enhancing the lake system's capacity to record climate changes (Giguet-Covex et al., 2012). Thickness and grainsize of flood layers are thus highly complementary parameters as a disturbance in their relationship can be interpreted as a catchment-scale disturbance of erosion patterns.

\subsubsection{Reconstructing erosion patterns from terrigenous lake sediments}

Even if flood events are the primary mechanism bringing sediment into lakes dominated by terrigenous-deposits, the evolution of soil dynamics and land cover may also be recorded in such environments. In particular, the nature of terrigenous organic matter as well as the degree of mineral weathering can be used to decipher soil evolution and associated erosion patterns (Giguet-Covex et al., 2011; Mourier et al., 2010, 2008; Poulenard, 2011). We showed at Lake Anterne that the post-glacial colonisation of superior plants in the catchment area resulted in a millennial-long drop in calcium content of terrigenous sediments (Giguet-Covex et al., 2011). This can be explained by preferential weathering of calcium carbonates in this catchment area composed of marls and limestones. From the same sequence we also evidenced changes in the erosion pattern by combining organic (oxygen vs. carbon proportion within organic matter) and minerogenic (ratio of mobile vs. immobile cations) markers of weathering degree of eroded materials. In particular, in the case of a single lithology catchment area, it is possible to distinguish material coming from deep vs. superficial soil horizons (Giguet-Covex et al., 2011).

\section{Holocene erosion patterns in the Alps}

\subsection{Lake Bourget as a regional reference record}

Lake Bourget yielded the longest regional continuous erosion record currently available around the Alps (Arnaud et al., 2012; Debret et al., 2010). Reconstructions of both quantity and quality of erosion fluxes (Fig. 6A) allow discussing the evolution of erosion patterns throughout the Holocene on a regional basis. The recorded erosion history can be schematised in 5 periods.

Period I. Between 11 and ca. $10 \mathrm{ka}$ cal. BP the sediment flux is largely dominated by terrigenous input. However, this was due to a geomorphological configuration different from today. Indeed, the Rhône River was entering directly and permanently into Lake Bourget whereas nowadays it flowing into the lake only during major floods through the so-called Canal de Savière. Unfortunately, this shift was almost contemporaneous with a huge landslide that affected most of the lake basin, precluding a direct dating of the studied sediment core. However, the shift led to the accumulation of peat that was created in the backswamp. The study of this peat accumulation yields an approximate age of $10 \mathrm{ka}$ cal. BP (Disnar et al., 2008) coherent with our assessment from the lake-core study, i.e. between 10.5 and $9.5 \mathrm{ka}$ cal. BP (Arnaud et al., 2012). Moreover, the study of the Rhône floodplain indicates that the Upper Rhône bottom load surpassed Lake Bourget starting just after $10 \mathrm{ka}$ cal. BP (Salvador and Berger, 2014). The inferred terrigenous flux from that period is not comparable with the one to follow. However, we observe that the nature of the sediment is dominated 

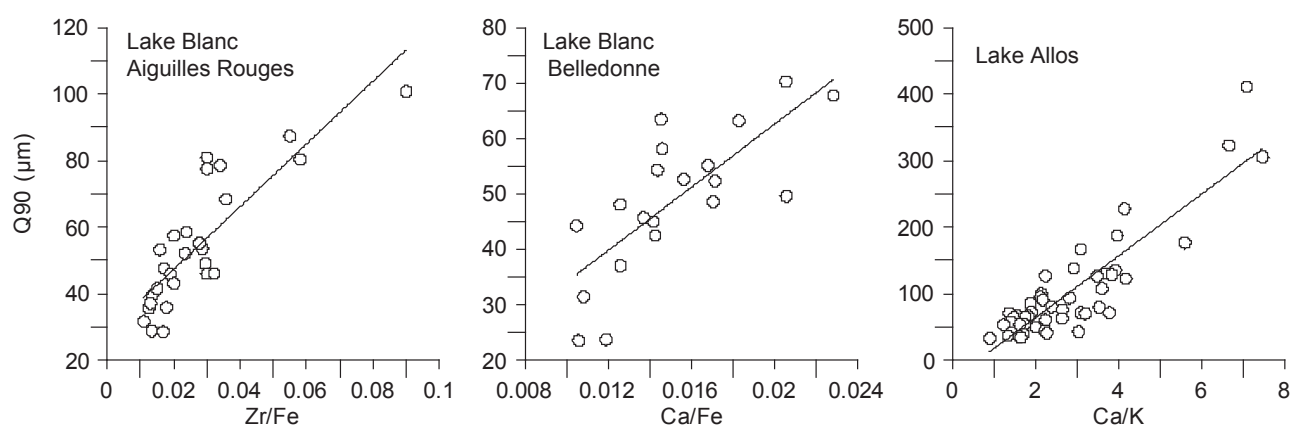

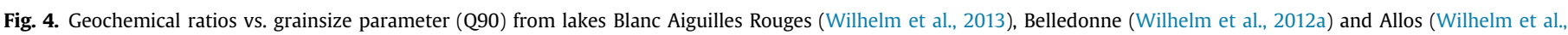
2012b).

by poorly weathered material (high $\mathrm{K} / \mathrm{Ti}$ ratio) with a relatively small contribution of the currently-glaciated Mont Blanc Massif $(\varepsilon N d<-10)$.

Period II. Between 9.5 and $4.7 \mathrm{ka}$ cal. BP, terrigenous fluxes are very low, ranging from 10 to $30 \mathrm{mg} \mathrm{cm}{ }^{-2} \cdot \mathrm{a}^{-1}$, with a mean close to $15 \mathrm{mg} \mathrm{cm}^{-2} \mathrm{a}^{-1}$ at site LDB01-I (Arnaud and Révillon, 2015). Regarding the nature of the eroded material the period should be divided in two parts. From 9.5 to $7.4 \mathrm{ka}$ cal. BP the physical erosion seems to dominate the weathering processes as indicated by high $\mathrm{K} / \mathrm{Ti}$ ratio. Moreover the $\varepsilon \mathrm{Nd}$ close to -9 points to an important contribution from the Mont Blanc massif. From 7.4 to $4.7 \mathrm{ka}$ cal. BP chemical weathering increases at a regional scale as shown by lower $\mathrm{K} / \mathrm{Ti}$ values. The concomitant drop in $\varepsilon \mathrm{Nd}$ values indicates an increasing contribution of lower elevation terrains to the sediment flux which remains very low. This shift in erosion source is further confirmed by the floodplain record that points to a major change in fluvial patterns and dynamics of the river Rhône around $7 \mathrm{ka}$ cal. BP (Salvador and Berger, 2014).

Period III. From 4.7 to $1.6 \mathrm{ka}$ cal. BP terrigenous fluxes slightly increase, ranging most of the time between 20 and $40 \mathrm{mg} \mathrm{cm}^{-2} \mathrm{a}^{-1}$, with maximum values exceeding $50 \mathrm{mg} \cdot \mathrm{cm}-2 \cdot \mathrm{a}-1$ during short periods of increased terrigenous flux. Noticeably, this change in terrigenous flux does not seem to be accompanied by a change in erosion source (cf. K/Ti ratio) which remains dominated by highly weathered material except during the longest erosion periods around $4.2 \mathrm{ka}$ cal. BP and during the last 5 centuries of period III. Indeed, from 2.2 to $1.6 \mathrm{ka}$ cal. BP we observe a markedly increasing trend in terrigenous flux that exceeds the value of $0.1 \mathrm{gcm}^{-2} \mathrm{a}^{-1}$ around $1.9 \mathrm{ka}$ cal. BP for the first time since the Rhône River shift. This increasing trend is accompanied by a continuous increase of the $\mathrm{K} / \mathrm{Ti}$ ratio indicating that physical erosion tended to become preponderant upon chemical weathering, whereas the provenance seems to have remained constant as indicated by stable $\varepsilon \mathrm{Nd}$ values of -10.61 , which is significantly lower than during the $4.2 \mathrm{ka}$ cal. BP erosion period ( -10.39 in average).

Period IV. At $1.6 \mathrm{ka}$ cal. BP a major shift in terrigenous input is recorded in Lake Bourget. Indeed, during two erosion peaks from 1.6 to $1.3 \mathrm{ka}$ cal. BP (i.e. from 350 to $650 \mathrm{AD}$ ) and even more from 0.8 to $0.05 \mathrm{ka}$ cal. BP (i.e. 1150 to $1900 \mathrm{AD}$ ) the terrigenous flux was always above $100 \mathrm{mg} \cdot \mathrm{cm}-2 \cdot \mathrm{a}-1$ and reached the highest value of $700 \mathrm{mg} \cdot \mathrm{cm}-2 \cdot \mathrm{a}-1$. During that period, the $\mathrm{K} / \mathrm{Ti}$ ratio follows the terrigenous input, indicating that the excess of erosion was produced by physical erosion. Moreover, during the main peaks in terrigenous flux we observe a shift in provenance marked by a rise in $\varepsilon N d$ values. This suggests that a substantial part of the excess in erosion originates from the Mont Blanc crystalline massif.

Period V. Since 0.05 ka cal BP (i.e., since 1900 AD), the terrigenous flux in Lake Bourget dropped back to values that were common prior to $1.6 \mathrm{ka}$ cal. $\mathrm{BP}$ just as the $\mathrm{K} / \mathrm{Ti}$ ratio, indicating a relative decrease in physical erosion processes at a regional scale.

The interest of the erosion reconstruction at Lake Bourget is largely due to the large size of the catchment area. However, over such a surface area, there is a great diversity of phenomena that potentially modified the erosion signal as it is recorded in the sediment. Among the potential causes of the evolution of erosion patterns, one can list i) climate change, mainly through changes in precipitation patterns; ii) glacier dynamics which can modulate the production rate of glacial clay; iii) soil-vegetation dynamics, affecting slope stability and iv) human land-use, mainly through deforestation and over-pasturing. Studying the quality of erosion products permitted to partly disentangle these factors. Moreover, we completed our investigation by i) studying smaller-scale lake systems in the Northern French Alps, in order to reconstruct what have been the local perturbations of the erosion cycle along an altitudinal gradient and ii) comparing those records with other independent records from all over the Alps, i.e. reconstructions of
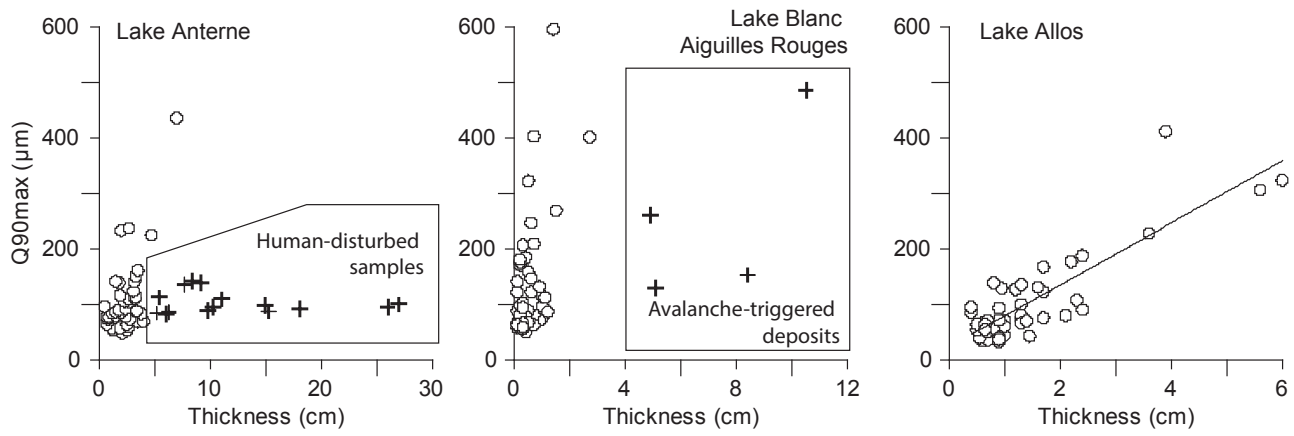

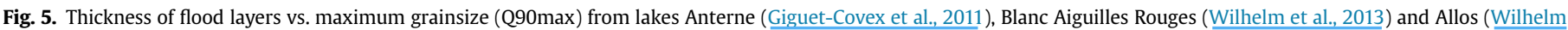
et al., 2012b). 


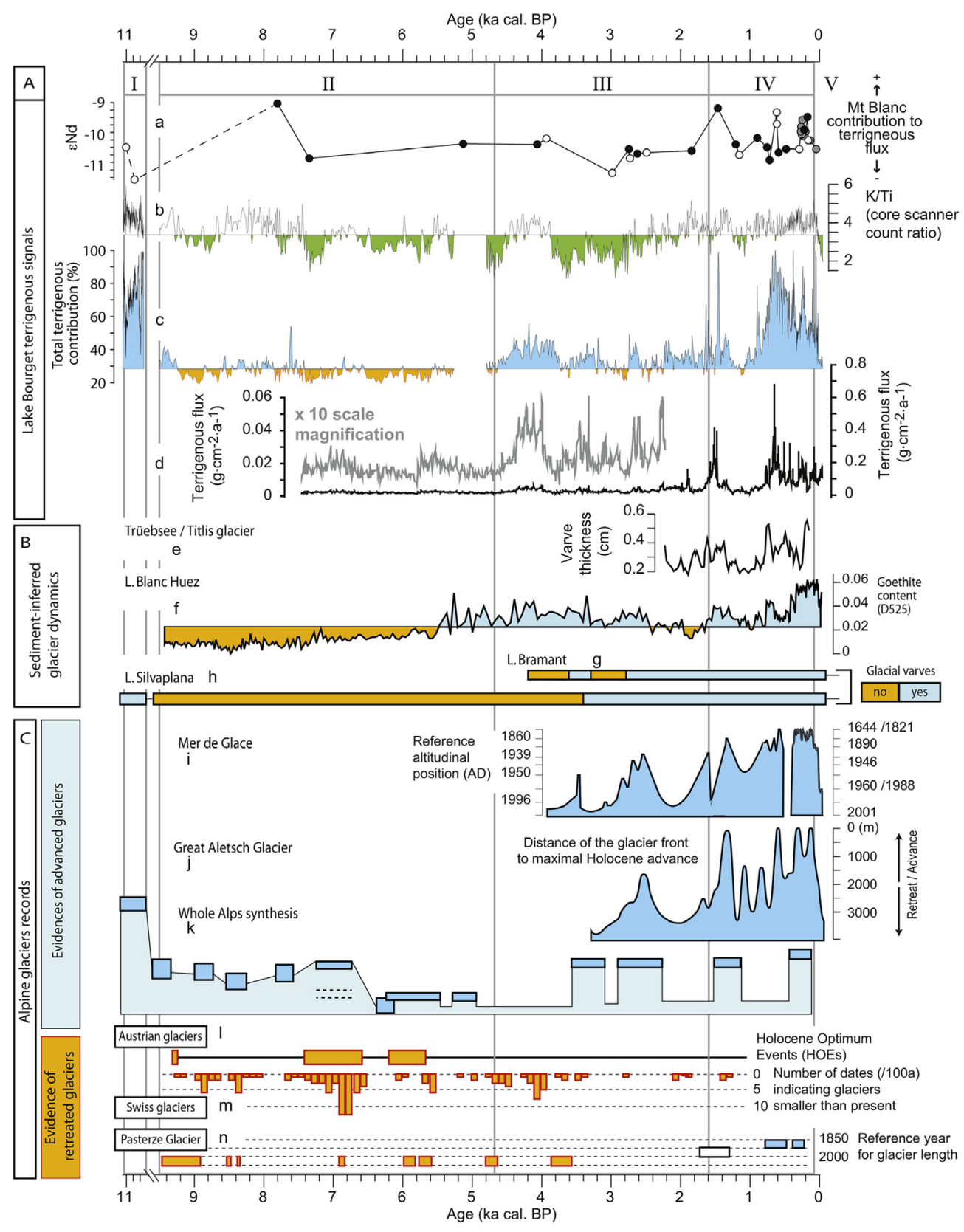

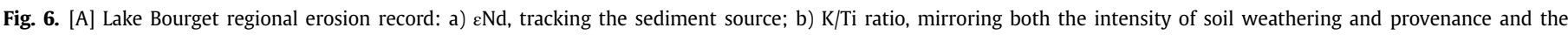

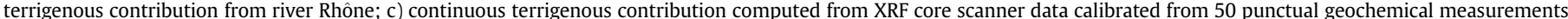

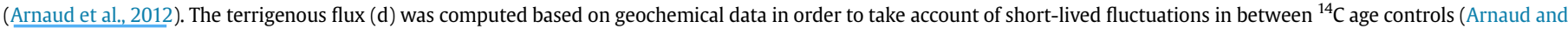

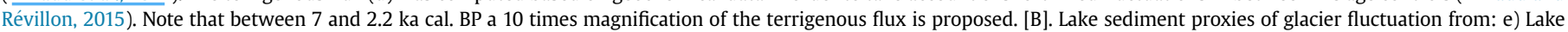

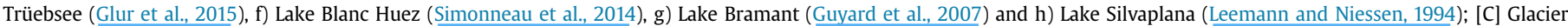

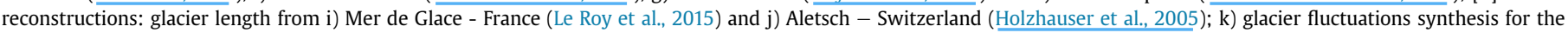

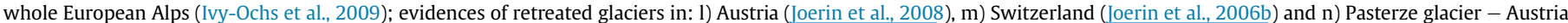

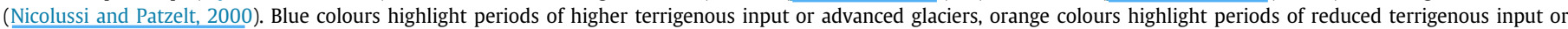

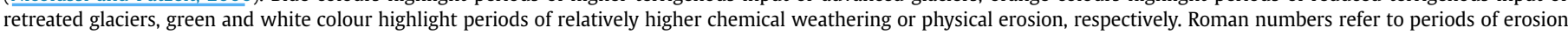
changes in Lake Bourget described in the text.

glacier dynamics (Fig. 6) and lacustrine erosion/flood records (Fig. 7).

\subsection{Erosion and glacier fluctuations}

In high-altitude mountain areas, such as the inner European Alps, glaciers are one of the most outstanding geomorphic agents acting on erosion. Indeed, glacial-interglacial oscillations literally paced the sediment budget over the last hundreds of thousands years (Hinderer, 2001; Hinderer et al., 2013). As a matter of fact, the last deglaciation resulted in a rapid infilling of over-deepened alpine valleys. Since the early Holocene, the flux of glacier-eroded material drastically dropped in response both to glacier recession and to the conquest of formerly ice-covered surfaces by vegetation. In perialpine lakes like Lake Bourget, this resulted in a drastic drop in sedimentation rates (Ndiaye et al., 2014; van Rensbergen et al., 1999). However, even during the Holocene, a marked influence of glaciers on the erosion budget has been noticed in several 


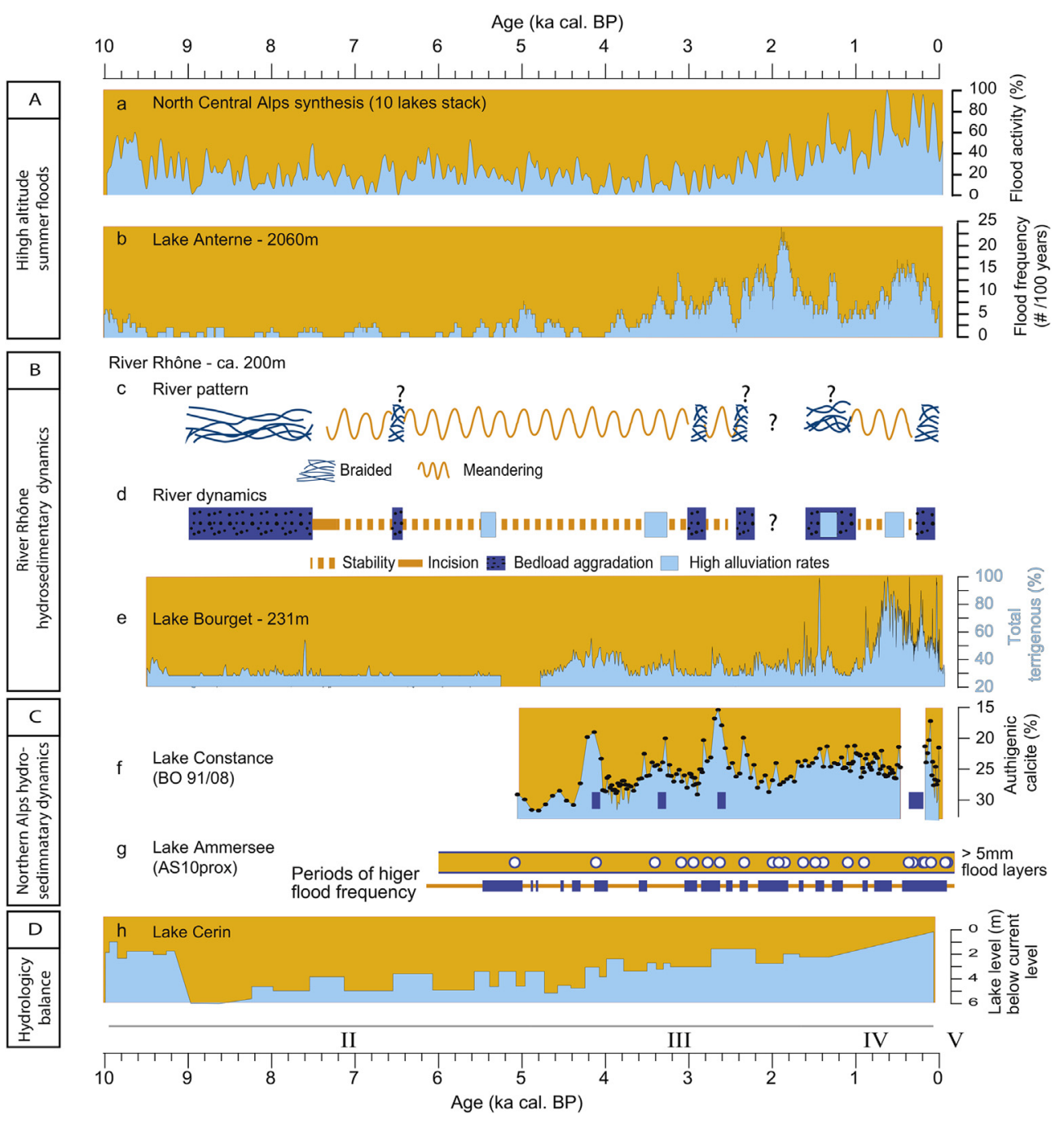

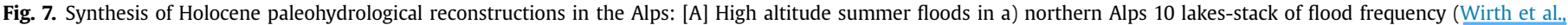

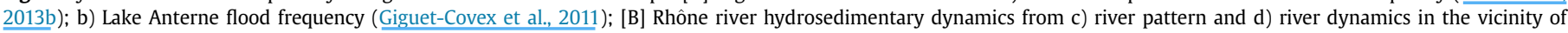

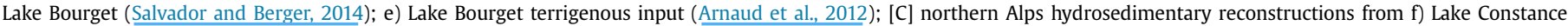

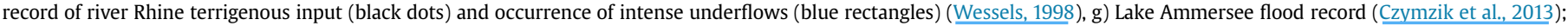

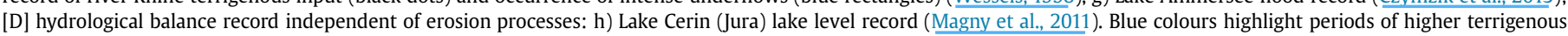

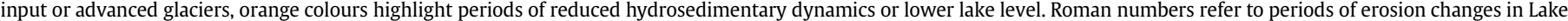
Bourget introduced in Fig. 6.

proglacial lake records (Glur et al., 2015; Guyard et al., 2007; Leemann and Niessen, 1994; Simonneau et al., 2014). One may, however, ask if such an influence was recorded in Lake Bourget sediment, i.e. at a regional scale. We reported in Fig. 6 (B and C) most of the available data about Holocene glacier dynamics in the Alps in order to compare them with the regional erosion record from Lake Bourget. Over several thousand years one observes a similar pattern in proglacial lakes and Lake Bourget signals. This points out an increase in erosion during the second half of the Holocene, whereas the timing of this shift seems to be sitedependent: ca. $5.2 \mathrm{ka}$ cal. BP at Lake Blanc Huez (Simonneau et al., 2014), $4.2 \mathrm{ka}$ cal. BP at Lake Bourget (Arnaud et al., 2012) and 3.2 ka cal. BP at Lake Silvaplana (Leemann and Niessen, 1994). This corroborates the nowadays consensus that alpine glaciers were more retreated than today over more than half of the Holocene (Goehring et al., 2011; Hormes et al., 2001; Joerin et al., 2006a; Nicolussi and Patzelt, 2000). On a shorter time-scale a comparison for the early Holocene period (prior to $5 \mathrm{ka}$ cal. BP) is only possible with the Blanc Huez record (Simonneau et al., 2014) and with the low resolution synthesis by Ivy-Ochs et al. (2009). There seems to be a certain fit between classically recognised phases of glacier advances. However, by that time the terrigenous flux is very weak and at the regional scale. One can get much more information for the second half of the Holocene, and especially since $4 \mathrm{ka}$ cal. BP, with the detailed tree-ring-based reconstructions of Aletsch (Holzhauser et al., 2005) and Mer de Glace (Le Roy et al., 2015), glacier advances as well as the lake sediment-based reconstruction of the glacier dynamics of Titlis (Glur et al., 2015). Over that period, most of Lake Bourget erosion signals are contemporaneous with glacier advances recorded elsewhere. A noticeable exception is the period between 2.4 and $1.8 \mathrm{ka}$ cal. BP when there is no obvious relationship between erosion flux and glacier fluctuations. The shift between Lake Bourget erosion periods III and IV is also well-marked in glacier dynamics, as the two last glacier advances are the most important and extended ones (Holzhauser et al., 2005; Le Roy et al., 2015).

Obviously, glacier dynamics and erosion evolved concomitantly during most of the Holocene. However such an observation does 
not imply a direct cause to effect relationship. Indeed, both could have been paced by the same forcing factors, i.e. climate change, without being directly linked together. This question remains hard to address, however some evidences tend to link both phenomena. First of all, the Trüebsee record attests the existence of high altitude sediment sources that directly depend on glacier activity (Glur et al., 2015). Downstream, the perfect match of the two last glacier advances - i.e. 350-650 AD and 1150-1900 AD - with a tenfold increase in terrigenous flux and a source shift toward the Mont Blanc crystalline massif (Arnaud et al., 2012) point to the noticeable contribution of this high altitude source in the late Holocene excess of terrigenous supply. At least for those two last periods, even if changes in terrigenous supply would have been mainly driven by hydrological conditions, more or less modulated by land-use, glacier dynamics obviously reinforced them. To go a step further and quantify the role of glacial erosion in the sediment budget throughout the Holocene would require to measure the $\varepsilon \mathrm{Nd}$ at higher resolution and to calculate the relative contribution of different sediment sources.

\subsection{Erosion and hydrological patterns}

Reconstruction of terrigenous input is often presented as mirroring hydroclimate changes (e.g. Haug, 2001). In the case of the Northern French Alps we came to the same conclusion studying the terrigenous signal of Lake Bourget. This conclusion is supported by the general agreement of this signal with the independent reconstruction of the River Rhône hydro-sedimentary dynamics (Salvador and Berger, 2014, Fig. 7c and d). Moreover, when compared with independent records, a general pattern for Holocene paleohydrology can be drawn (Fig. 7). Interpreted as a paleohydrological reconstruction, the evolution of terrigenous discharge in Lake Bourget (Fig. 7e) presents a maximum for the Early Holocene, a drastic drop around $10 \mathrm{ka}$ cal. BP and a reincreasing trend since $4.4 \mathrm{ka}$ cal. $\mathrm{BP}$, culminating during the Little Ice Age prior to a strong decrease over the last century. A similar pattern can be deduced from lake level-based hydroclimate reconstructions in the vicinity of Lake Bourget (Lake Cerin, Fig. 7h; Magny et al., 2011). When comparing it to growing evidences that alpine glaciers were most of the time more retreated than today during first half of the Holocene (Goehring et al., 2011; Hormes et al., 2001; Ivy-Ochs et al., 2009; Joerin et al., 2006a, Fig. 6C), one may assume that such a "reduced-glacier state" of the Alps was at least partly due to particularly dry conditions. Looking at the Holocene reconstructions of extreme floods (Giguet-Covex et al., 2011; Wirth et al., 2013b, Fig. 7a and b) the same pattern appears, suggesting a correlation between the frequency of extreme floods recorded in high altitude lakes, and average precipitation recorded both by large perialpine lake records and by lake-level reconstructions.

It is remarkable that even for short-lived fluctuations of erosion a link with climate oscillation evidenced elsewhere can be found (Arnaud et al., 2012). The most outstanding temporal fit is probably the almost perfect match of Lake Bourget and the River Rhône discharge record with the distant record of the Rhine discharge into Lake Constance (Wessels, 1998, Fig. 7f) between 5 and 1 ka cal. BP. A similar pattern is observed for Lake Ammersee flood records (Swierczynski et al., 2013, Fig. 7g), except around 2000 cal. BP when a period of higher flood frequency is recorded only in Ammersee.

However, looking at the details these conclusions must be temperate. Indeed, we showed that the link between precipitation and erosion can never be considered as a direct transfer function. To our knowledge, very few studies were able to give a quantified relationship between erosion signals and precipitation parameters. Trachsel et al. (2008) for instance, found a relationship between a mineralogical ratio and hydroclimate parameters. However, it was calibrated over the instrumental measurement period and there is no guarantee that such a relationship remains stable along millennia. To verify this, one should model the relative impact of all forcing factors on erosion, which still remains a scientific challenge. Another attempt of quantification was performed for Lake Bourget over the last century through the reconstruction of water discharge related to past extreme floods (Jenny et al., 2014). Due to the complex sedimentological features of large lakes, we had to use a set of 24 sediment cores in order to map and assess the volume of flood deposits associated to the 30 largest floods over the last 250 years. A calibration with monitoring data revealed a significant relationship between sediment volume deposited by each flood event and water discharge of individual historic events. This is probably a track to be followed in order to reconstruct past discharge events. However, one may not completely rule out the fact that the relationship between sediment and water discharge can vary through time, just like shown for high altitude Lake Anterne (Giguet-Covex et al., 2012).

In high altitude systems dominated by terrigenous sediments erosion flux largely depends on the occurrence of extreme events. For instance, in Lake Anterne (Giguet-Covex et al., 2012) we showed that sediment input is exclusively triggered by flash-flood events. In such a context only few events play an important role for the export of sediment from the catchment area. Since $3.5 \mathrm{ka}$ cal. BP, 331 floodevents brought $40 \%$ of the 13.4 m-thick sediment accumulation. If we assume each "event" lasted one day, this means that $40 \%$ of the 3500 year-long sediment accumulation was brought during 331 days, i.e. $0.025 \%$ of the whole period. Moreover, the individual thickness of flood deposits in Lake Anterne varies between 4 and $268 \mathrm{~mm}$, with an average of $16.5 \mathrm{~mm}$ per event. To establish a reliable age-depth model we usually remove the $>5 \mathrm{~mm}$ extreme events. This led us to compute an average $2.2 \mathrm{~mm} \mathrm{a}^{-1}$ sedimentation rate. By comparison extreme flash floods produce 2- to 130 fold (8-fold in average) higher sedimentation rates. These erosion processes are strongly dependent on the occurrence of rare but extreme precipitation events. This particularity has been exploited tackling past extreme-event chronicles (see for instance: Bøe et al., 2006; Czymzik et al., 2013; Francus et al., 2008; Lamoureux et al., 2001; Nesje et al., 2001; Støren et al., 2010; Swierczynski et al., 2013). In the European Alps, a detailed study was carried out for Lake Ledro (Simonneau et al., 2013a; Vannière et al., 2013; Wirth et al., 2013a). Furthermore, the "FloodAlp!" project (Anselmetti et al., 2014; Gilli et al., 2013; Glur et al., 2015, 2013, Wirth et al., 2013a, 2013b) permitted the establishment of 15 original lake sediment-based flood chronicles (including Lake Ledro) along a north-south transect throughout the Central Alps, from 200 up to more than $2000 \mathrm{~m}$ in altitude. One of the main outputs was the establishment of two remarkable Holocene flood-frequency curves for the northern and the southern flanks of the Central Alps, stacking 10 and 5 lake records, respectively (Wirth et al., 2013b). We reported the Northern Alps curve in Fig. 7a. Such a dataset does not exist for the French Alps where the sequence of Lake Anterne is only a Holocene high altitude flood series (Giguet-Covex et al., 2012, Fig. 7b). Both curves display a similar general pattern like the Lake Bourget terrigenous input signal, whereas they differ in details.

Over the last 1400 years (Fig. 8), data from lakes Blanc Aiguilles Rouges (Wilhelm et al., 2013, Fig. 8c), Anterne (Giguet-Covex et al., 2012, Fig. 8d) and Allos (Wilhelm et al., 2012b, Fig. 8e) provided reconstructions of flood frequency and intensity. Brought together with the regional records of Lake Bourget (Fig. 8a) and the northern Alps flood activity curve (Fig. 8b) those high altitude records reveal a strong and common reaction to the so-called Little Ice Age cold spell which corresponds with an increase in flood frequency at high 
elevation sites and a rise in terrigenous flux at a regional scale. However, high frequency decadal variability is far less coherent. The climatic interpretation lies beyond the scope of this review, however, results from high altitude records highlight the complex response of the hydrological cycle to climate change. Based on those results we pointed out that colder periods generally favour higher flood frequency all around the Alps, but they are marked by high flood intensity only in the Southern Alps (Wilhelm et al., 2012b). In order to confirm this hypothesis, further paleostudies are required to tackle in detail both the intensity and the geographic extension of past extreme flood events in the Alps.

Regarding the Holocene erosion history of the Alps, studies of high altitude terrigenous-dominated lake sediment records pointed to the extreme dependence of upper catchment areas to climate changes and in particular to the evolution of extreme events, both in frequency and in intensity. However, we also showed that the relationship between heavy precipitation and the deposit of a given "flood layer" can be modulated by landscape dynamics, in particular under human pressure. For Lake Anterne, we show that the vulnerability of soils to heavy rainfall-induced erosion increased around $3.5 \mathrm{ka}$ cal. BP (Giguet-Covex et al., 2012) with the reinforcement of pasturing activities (Giguet-Covex et al., 2014). In that particular case, this resulted in a more accurate record of high frequency climate variability over the last 3500 years, but precluded a direct comparison with previous periods. As a consequence, this point needs to be taken into account seriously when establishing geological records of past flood patterns, particularly in the European Alps where human activities in the mountains began as early as Neolithic (ca. 7 ka cal. BP). As a consequence, cautioun is advised for any flood reconstruction from lake systems located in areas suited for human activities.

\subsection{Erosion and soil dynamics}

Changes in human land-use and more generally speaking, changes in land-cover, affect erosion patterns in a way that can be recorded by geological archives (Dearing, 1983; Dearing et al., 1987, 1986; Foster et al., 1985; Gillieson et al., 1986; Oldfield et al., 1980). As a consequence, climate is not the sole forcing of erosion processes. In the 2000's the key was to "disentangle human and natural - i.e climatic - signals" (Lottermoser et al., 1997; Zolitschka et al., 2003) or even "to clean the climate signal from human

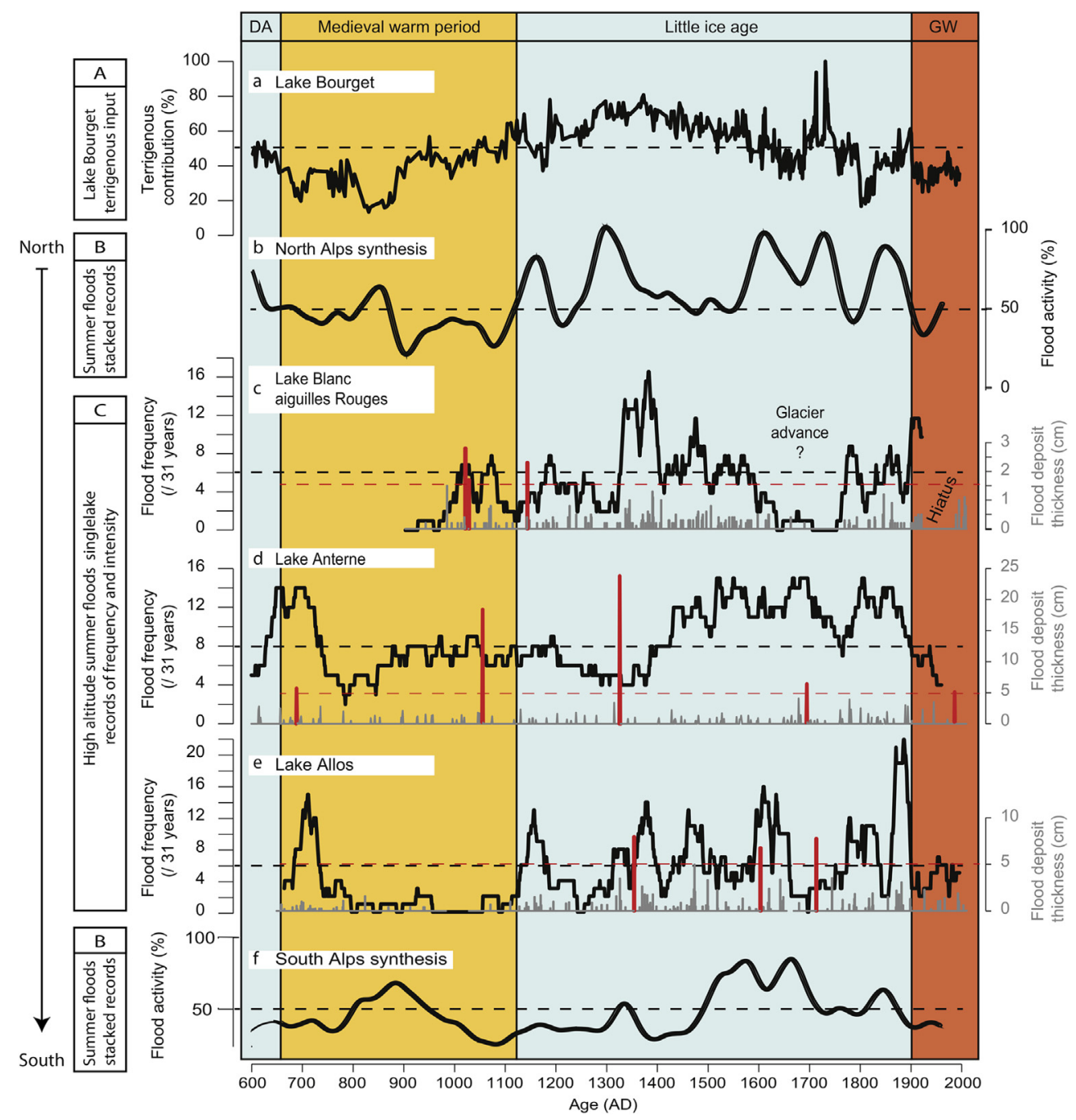

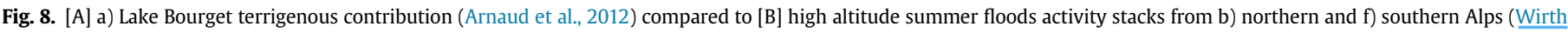

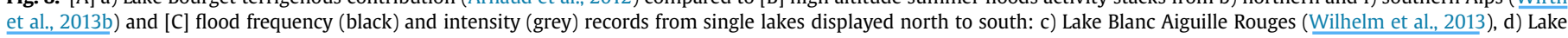

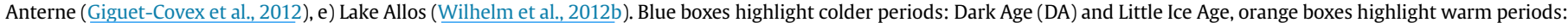

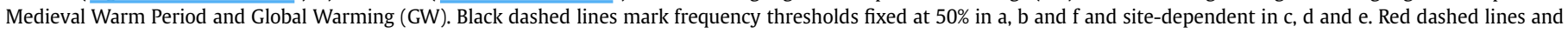
vertical bars mark intensity thresholds fixed at $1.5 \mathrm{~cm}$ in $\mathrm{c}$ and $5 \mathrm{~cm}$ in $\mathrm{d}$ and e. 
noise" (Jones et al., 2013). Interestingly, some years before the aim was "to clean up the geodynamic signal from the climate noise" (Beck et al., 1996). The recent emergence of the Anthropocene concept and the growth of interest for sustainability reactivated the interest to understand to what extent erosion patterns were modified by human activities in the recent past. It was argued that human-triggered erosion changes (Poirier et al., 2011), soil transformation (Certini and Scalenghe, 2011) or the effect of land-use on the carbon cycle (Ruddiman, 2003) could define the Anthropocene period itself.

In our case, we carried out a process-based study without any $a$ priori forcing factor. In that sense, we follow the line drawn by (Costanza et al., 2007) and try to decipher an "integrated history of humans and the rest of the Nature". We synthesized in Fig. 9 the results from 5 10,000 years-long sediment sequences taken along an altitudinal gradient in the Northern French Alps from 230 to $2060 \mathrm{~m}$ asl. Their catchment areas span a vertical gradient of $4600 \mathrm{~m}$ and a large range of land-cover conditions (from forested soils to glacier-covered bare rocks) and land-uses (agriculture, forestry, pasturing). We observe a general rise in erosion signals during the last $10 \mathrm{ka}$ localised small catchment areas as well as in the regional record of Lake Bourget.

In the earliest period (10-4.2 ka cal. BP), erosion is generally very low in the Alps and not detectable at lowest altitudes (Lakes Moras, Paladru, La Thuile; Fig. 9c, d, e) that were covered by forest for thousands of years. In higher altitudes (Lake Anterne; Fig. 9a, b) soil formation processes are active until at least $8 \mathrm{ka}$ cal. BP and documented by a continuous drop in Ca content in the sediment (Fig 9a), tracking a noticeable weathering activity. Until 8 ka cal. BP, the regional record of Lake Bourget is dominated by poorly weathered material (high $\mathrm{K} / \mathrm{Ti}$ ratio) confirming that the conquest of soils towards highest elevation is still ongoing.

Soil formation appears to reach a climax around $8 \mathrm{ka}$ al. BP when evidences of relatively dense vegetation (David, 2010a, 2010b; Pansu et al., 2015) and stabilisation of weathering processes (Giguet-Covex et al., 2011) are recorded within Lake Anterne catchment area. In Lake Bourget the K/Ti ratio (Fig. 9g) drops around $8 \mathrm{ka}$ cal. BP pointing to the dominance of weathering processes upon physical erosion. This confirms the onset of the Holocene pedogenesis optimum at $8 \mathrm{ka}$ cal. BP. However, the drop in $\varepsilon \mathrm{Nd}$ values indicates a drop in contribution from Mont Blanc. It does not permit to rule out the influence of a provenance change, e.g. the stabilisation of soft sediments inherited from the glacial period.

A first threshold was reached between 5 and $4 \mathrm{ka}$ cal. BP, when the regime of soil formation appeared to change. This corresponds to the onset of the so-called Holocene Neoglacial period (Davis et al., 2003; Deline and Orombelli, 2005). In our records, it is marked in Lake Anterne by a return to oxic bottom water conditions, the rise in flood frequency (Fig. 9b) and a trend toward the erosion of uppermost soil horizons (Giguet-Covex et al., 2011). At that time DNA data point to the rapid recession of arboreal plants and associated ecosystems (Pansu et al., 2015). Around 4 ka cal. BP a drastic drop in arboreal pollen and more particularly in fir pollen is also noticed in the catchment area of Lake Anterne (David, 2010a) which confirms the recessing trend of the forest ecosystem. At a regional scale, the erosion period between 4.6 and $3.8 \mathrm{ka}$ al. BP, evidenced both in lakes Bourget and Constance, marks the return of a poorly weathered sediment source without apparent reinforcement of the Mont Blanc provenance. This points to the return of physical erosion conditions at a period when important climate changes occur in the Alps (Magny et al., 2009; Schmidt et al., 2002).

Whatever is the cause, a threshold was reached around $4 \mathrm{ka}$ cal. BP: since then the regional erosion signal remained higher than during the previous 5 millennia. Until $2.2 \mathrm{ka}$ cal. BP, rapid and moderate fluctuations in erosion - recorded both in lakes Bourget and Constance - are accompanied in Lake Bourget by recurrent drops in $\mathrm{K} / \mathrm{Ti}$ indicating short intensifications of erosion processes. The climatic origin of those wiggles is suggested by the perfect match between the records from lakes Bourget and Constance (Fig. 7c, f). Their geochemical signature in Lake Bourget suggest a rise of the Mont-Blanc source and/or an increase in physical erosion rates following those short-lived and low intensity climate oscillations. By that time Lake Anterne experienced a continuous rise in apparent flood frequency, but also an intensification of soil-erosion processes (Giguet-Covex et al., 2011). This was interpreted by Giguet-Covex et al. (2012) as the result of a reinforcement of pasturing activities and further confirmed by the oldest evidence of sheep DNA from sediment of Lake Anterne dated to $3.5 \mathrm{ka}$ cal. BP (Giguet-Covex et al., 2014).

At lowest elevation sites, despite evidences of Bronze Age human occupations (Jacob et al., 2009, 2008a; Magny et al., 2012), none of our low altitude lake records experienced any rise in erosion at that period. Similarly and despite evidences of land-use, pollen records indicate the persistence of dense forests around each of the three sites (Bajard et al., 2015; Doyen et al., 2013; Simonneau et al., 2013b) as well as around Lake Bourget (Gauthier and Richard, 2009). However, Jacob et al. (2009) noticed a change in agricultural practices at $3.7 \mathrm{ka} \mathrm{cal}$. BP when the first presence of broomcorn millet in the Alps was revealed by the detection of a specific biomarker (the so-called "milliacine") in the Lake Bourget sediment record. At that time, another molecule - 3,3,7-trimethyl-1,2,3,4tetrahydrocrysene (TTHC) - was detected and interpreted as a marker of erosion from uppermost soil horizons. The same conclusion was proposed around Lake Paladru based on a peak in soil organic remains (Simonneau et al., 2013b).

To summarize, it seems that Bronze Age agricultural practices were such that they did not generate deforestation or erosion in low altitudes where they, however, led to moderate erosion of uppermost soil horizons. On the contrary, at higher altitudes the reinforcement of pastoral activities led to a marked rise in physical erosion intensity which made those environments more sensitive to climate oscillations. This last observation is in agreement with data from the Northern and Central Alps which dated the onset of intensive land-use at high altitudes around $3.5 \mathrm{ka}$ cal. BP (Schmidt et al., 2002).

A very important threshold was subsequently reached during the late Iron Age, around $2.2 \mathrm{ka}$ cal. BP (ca. $200 \mathrm{BCE}$ ). At that time a drastic rise in erosion occurred at low altitude sites, especially in lakes Moras and Paladru catchment areas, in which no measurable erosion signal had been recorded before. At Lake La Thuile the rise occurred slightly earlier and was less marked. In all three cases, the human cause of this period of intense erosion leaves no doubt as it was accompanied by pollen related to forest clearance (drop in arboreal pollen, presence of charcoal in Lake Paladru) and pasturing (ruderal plants). For Lake Anterne we showed (Fig. 5) that the contemporaneous rise in flood frequency was accompanied by a decoupling between flood-layer grainsize (tracking current velocity) and thickness (tracking the sediment yield) (Giguet-Covex et al., 2012). This is interpreted as a major human-triggered disturbance of the catchment and was further attested by the discovery of archaeological pastoral remains and above all the detection of more cattle and sheep DNA in the sediment than in any other period. The intensity of this erosion phase in Anterne was such that the eroded material went very close to the signature of bedrock. This observation questions the sustainability of human practices by that time which probably affected the productivity of alpine ecosystems. Finally, the comparison with purely climatic records, such as the Mer de Glace glacier chronicle (Le Roy et al., 2015, Fig. 9h) for instance, indicates there was no climate change at that time to trigger such a change in erosion. At a regional scale, 


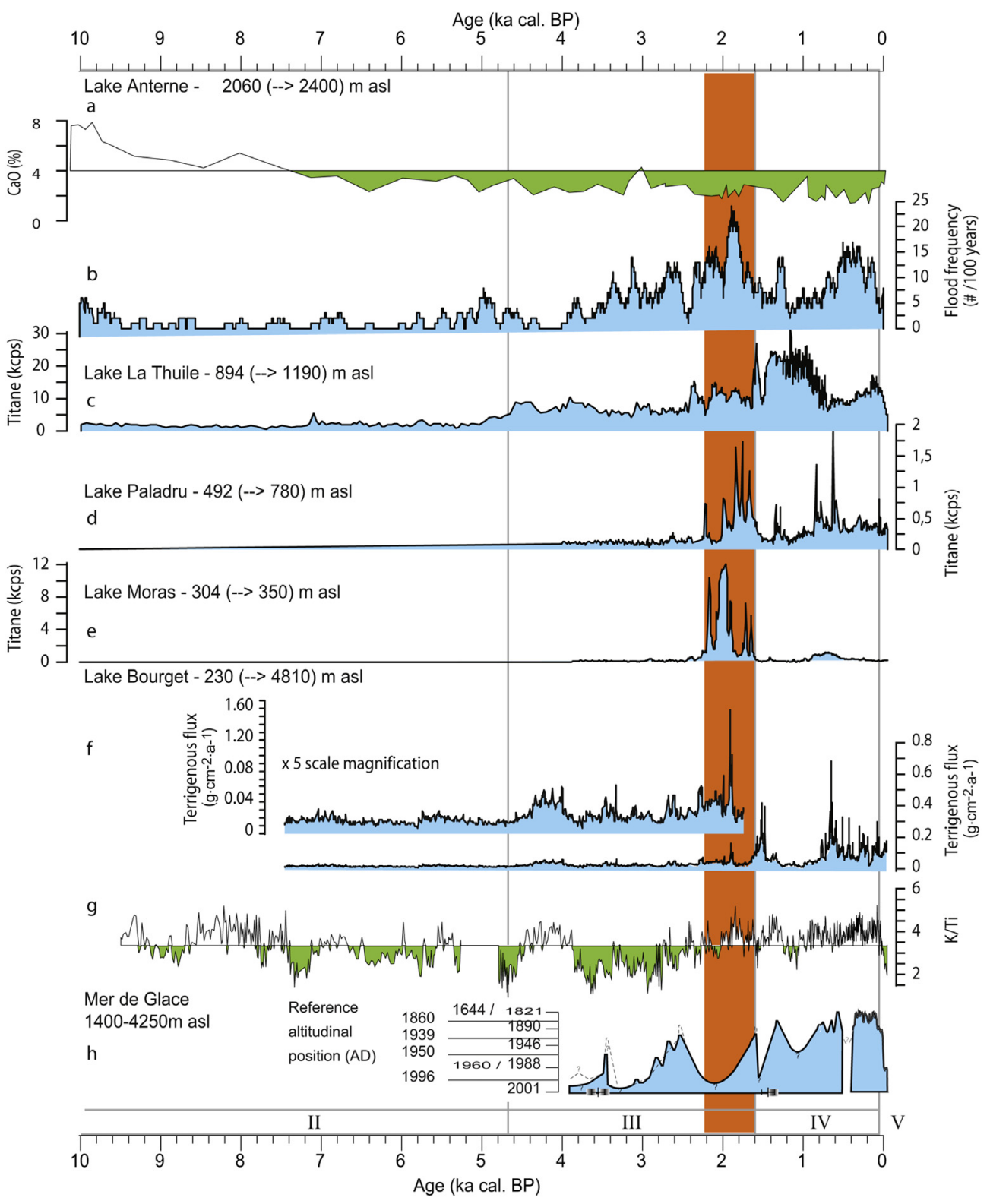

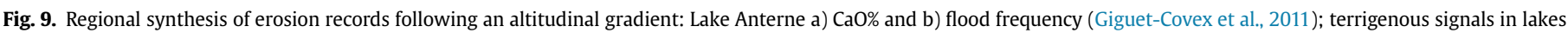

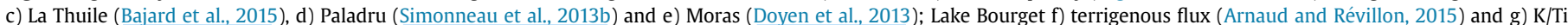

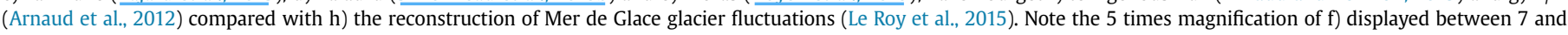

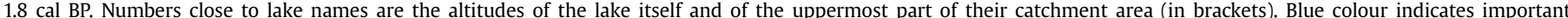

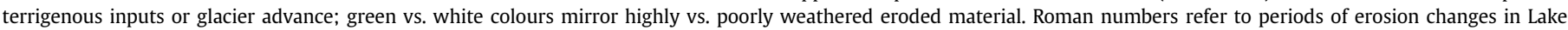
Bourget introduced in Fig. 6. The orange box highlights the supposed period of high human impact on erosion from $200 \mathrm{BCE}$ to $400 \mathrm{AD}$.

this period is only marked by a relatively moderate rise of terrigenous input in the Lake Bourget record. This can be explained by relatively dry climate conditions (glacier recession) which did not permit to export the sediment that was mobilised in higher parts of the catchment area. It was probably stored at their slope toe and in floodplains, due to low hydrological competence of streams. Noticeably, this erosion phase in Lake Bourget is the only which does not correspond to a period of intense floods in Lake Constance (Fig. 7f; Wessels, 1998). One may notice a shift in erosion patterns toward stronger physical erosion in response to the stronger incision throughout the Rhône catchment area. This increase in erosion is disconnected from any known local climate change, we are attempted to attribute it to practices of human landuse.

The pattern of intense erosion in small catchments and deficient export of sediment toward remote sinks lasted until 1.8 ka cal. BP (ca. 200 AD). During these more than four centuries, local populations apparently specialised in farming and more particularly pasturing which drastically changed the landscape even at low altitudes. Further studies would be necessary to assess the impact of that period on alpine ecosystems, biodiversity and functioning as well as its heritage through time, potentially until today.

The last 2000 years in the French Alps were marked by large oscillations in erosion patterns. The general trend is dominated by the so-called "Dark Age" and "Little Ice Age" cold spells which led to increases of regional sediment export as recorded in Lake Bourget. However, at the scale of small catchment areas the picture is not that clear. At lowest altitudes, lakes Moras and Paladru catchment areas rapidly recovered from the Late Iron Age extreme erosion 


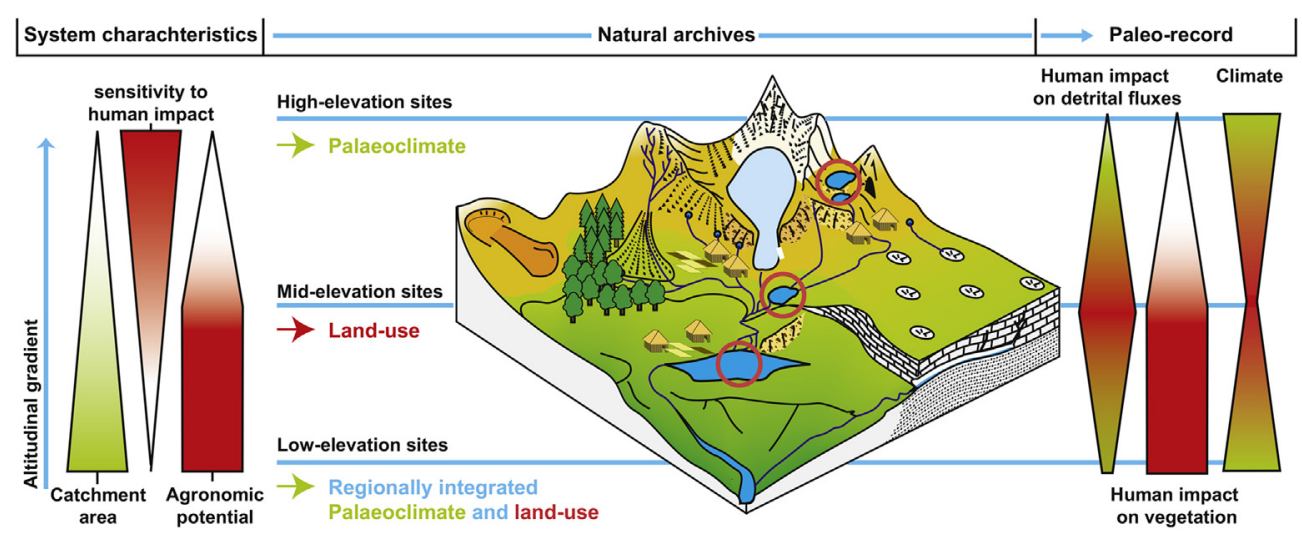

Fig. 10. Conceptual model linking mountain lake system characteristics and the information that can be expected from the study of their sediments.

phase, reaching a new steady state. This seems to have been a response to the onset of cultural meadows which were protective enough to preserve soils from erosion in those hilly landscapes. In both cases, the Dark Age is hardly detectable in terms of erosion. The Little Ice Age is slightly more marked at Lake Moras and clearly defined at Lake Paladru, particularly in the early stages of the period. At Lake Anterne the same scheme appears with virtually no signal during the Dark Age when the catchment probably recovered from the previous over-grazing period. Strong erosion is thereafter recorded in the second half of the Little Ice Age when pasturing activities reached a new maximum. Remarkably, the Lake La Thuile record displays a completely different pattern. Here the maximum of erosion is reached during the early Middle Age, when all other records are at minimum. The subsequent decrease in soil erosion, i.e. during the Little Ice Age, could be attributed to abandoned cultural landscapes due to harsh climate conditions. However, we are not convinced by this hypothesis as we know from historic sources that this region was intensively inhabited during the whole modern times. This is also supported by pollen data which do not point to any abandonment of human activities (Bajard et al., 2015). We tend to think that humans adapted their practices more or less intentionally, in order to limit erosion processes and make them more sustainable. Confirming this interpretation remains challenging. Unpublished DNA data evidence the onset of fruit-tree cultivation by that time (Giguet-Covex, 2015; Giguet-Covex et al., submitted) and tend to support this view. If confirmed, this would change our point of view on human practices and erosion, pointing to the fact that humans as a geological factor are able to intentionally modify and preserve the ecosystem services from which they depend.

Our records are not detailed enough to discuss human impacts on erosion processes of the last century. However, this would be an interesting research topic as this period was marked both by an abandonment of agricultural practices and by the intense reinforcement of human presence at high altitudes with the development of tourism, especially in ski resorts. The generally recorded trend points to a drastic drop in sediment transfer over the last century in the studied catchments. Noticeably, the imprint of human societies shifted from the export of eroded material toward the input of nutrients in water bodies, leading to a rapid and intense eutrophication.

\section{Conclusions and perspectives}

Over the last 15 years, we studied erosion processes and their evolution throughout the Holocene. We were able to create knowledge about Holocene hydroclimate variability and growing human influence upon Alpine landscapes. Erosion-based paleohydrological studies thus confirmed glacier-based studies arguing in favour of a particularly dry period between 10 and $4 \mathrm{ka}$ cal. BP in the European Alps. This is marked both in terms of regional erosion pattern (Arnaud et al., 2012) and flood frequency (Wirth et al., 2013b). At a higher temporal and spatial resolution it was also possible to propose decoupled dynamics between the northern and the southern Alps regarding temperature, flood frequency and flood intensity (Wilhelm et al., 2016b, 2013, 2012b). This highlights the complexity of precipitation-pattern responses to climate change at a regional scale.

Based on a better knowledge of hydroclimate fluctuations and novel human activity proxies, we highlighted a human-triggered erosion anomaly at the end of the Iron Age in the Northern French Alps. The spatial extension of this anomaly is not yet fully documented. This demonstrates the importance of developing a dense network of observations in order to detect and explain human-induced disturbances and to assess their relative importance in terms of local to global changes.

We documented the importance of developing ambitious research programs focused on the search for an accurate timespace description of erosion dynamics. This is now made possible by a growing capacity of analytical tools, in particular nondestructive techniques. However we also showed that novel proxies and detailed process analyses are required to move knowledge frontiers a step forward. Paleoscientists should collaborate together on multiproxy studies focusing on a selection of sites chosen because they can help to answer specific questions, rather than using new approaches in new sites. From our experience, this gave tremendous and unexpected results when we re-used sediment cores several years after their collection, using proxies we did not even expect to exist when the core was taken (Giguet-Covex et al., 2014; Jacob et al., 2008a). Generalising sample re-use will only be possible if the scientific community is able to wisely preserve, curate and make available samples from well-studied sediment sequences. Only this will permit capitalising successively acquired knowledge as well as developing new proxies.

We schematised in Fig. 10 the relationship between mountain lakes characteristics and the kind of information that can be expected from their terrigenous sediment. Basically it shows that the sensitivity of such systems to human impact is higher while their catchment area is smaller. In general this catchment area is smaller for higher altitude lakes, however, over a certain altitude - that is site-dependent - the agronomic potential drastically drops making the probability of human disturbance very low. This model points the importance of considering each record as itself and of leading spatialized multi-parameters studies in order to tackle the spatial 
and temporal complexity of human-climate-environment interactions.

Finally, just as it is obvious that the confrontation of proxies with paleoclimate model outputs was the key to modern scientific understanding of global climate dynamics, the same should now be performed regarding complex interplays ruling the evolution of the Earth critical zone. Elementary modules (erosion, vegetation dynamics, soil pedogenesis, weathering) are well known. However, we still miss an integrated model that takes account of the large panel of data that can be acquired from nature, whether it is a single site or a network of sites. We definitely think such a development is one of the crucial points to go a step further in the understanding of complex interplays between humans and the Earth and a prerequisite to better anticipate our future living conditions on Earth.

\section{Acknowledgements}

This paper is the result of a collective effort which began in the late 1990s' under the impulse of Marc Desmet and Marie Revel. We wish to warmly thank both. It was continued thanks to several research programs, namely APHRODYTE I and II, supported by CNRS INSU "Eclipse" call and PYGMALION, supported by the French National Agency for Research (ANR grant ANR BLAN07-2_204489). Charline Giguet-Covex was supported by the French Ministry of Research, Bruno Wilhelm by the Communauté de commune des balcons de Belledonne and the Assemblée des Pays de Savoie (APS), Jean-Philippe Jenny by the ANR and the APS, Lauretn Fouinat by the ANRT, Parc National des Ecrins and Communauté de communes de l'Oisans and Manon Bajard by the Foundation Montagne Vivante and the APS. Dirk Enters' stay at the Universite de Savoie was granted by the French Ministry of Research. We thank the Laboratoire de Mesure 14C (LMC14) ARTEMIS in the CEA Institute at Saclay (French Atomic Energy Commission) for most of 14C analyses used to establish age-depth models (CNRS-SHS and CNRSINSU programmes). Dr. Yves Perrette helped us in designing Fig. 10. The authors wish to thank Quaternary Science Reviews' editorial board and in particular Prof. Neil Roberts for soliciting the present article. We greatly thank Matthias Hinderer and an anonymous reviewer who brought comments which greatly improved the original manuscript.

\section{Appendix A. Supplementary data}

Supplementary data related to this article can be found at http:// dx.doi.org/10.1016/j.quascirev.2016.09.018

\section{References}

Anadón, P., Moscariello, A., Rodríguez-Lázaro, J., Filippi, M.L., 2006. Holocene environmental changes of lake Geneva (lac léman) from stable isotopes $(\delta 13 \mathrm{C}$, $\delta 180$ ) and trace element records of ostracod and gastropod carbonates. J. Paleolimnol. 35, 593-616. http://dx.doi.org/10.1007/s10933-005-4009-5.

Anderson, R.S., Jiménez-Moreno, G., Carrión, J.S., Pérez-Martínez, C., 2011. Postglacial history of alpine vegetation, fire, and climate from Laguna de Río Seco, Sierra Nevada, southern Spain. Quat. Sci. Rev. 30, 1615-1629. http://dx.doi.org/ 10.1016/j.quascirev.2011.03.005.

Anselmetti, F.S., Wirth, S.B., Glur, L., Gilli, A., 2014. Holocene flood frequency as reconstructed by lake sediments from multiple archives: a record influenced by solar forcing and atmospheric circulation patterns. GEOREVIEW Sci. Ann. Stefan Cel. Mare Univ. Suceava Geogr. Ser. 0, 1-2. http://dx.doi.org/10.4316/ GEOREVIEW.2014.0.0.178.

Arnaud, F., Lignier, V., Revel, M., Desmet, M., Beck, C., Pourchet, M., Charlet, F., Trentesaux, A., Tribovillard, N., 2002. Flood and earthquake disturbance of $210 \mathrm{~Pb}$ geochronology (Lake Anterne, NW alps). Terra Nova 14, 225-232. http:// dx.doi.org/10.1046/j.1365-3121.2002.00413.x.

Arnaud, F., Magand, O., Chapron, E., Bertrand, S., Boës, X., Charlet, F., Mélières, M.-A., 2006. Radionuclide dating (210Pb, $137 \mathrm{Cs}, 241 \mathrm{Am})$ of recent lake sediments in a highly active geodynamic setting (Lakes Puyehue and Icalma-Chilean Lake District). Sci. Total Environ. 366, 837-850. http://dx.doi.org/10.1016/ j.scitotenv.2005.08.013.
Arnaud, F., Revel, M., Chapron, E., Desmet, M., Tribovillard, N., 2005. 7200 years of Rhône river flooding activity in Lake Le Bourget, France: a high-resolution sediment record of NW Alps hydrology. Holocene 15, 420-428. http:/ dx.doi.org/10.1191/0959683605hl801rp.

Arnaud, F., Révillon, S., 2015. A geochemical approach to improve radiocarbonbased age-depth models in non-laminated sediment series. In: Micro-XRF Studies of Sediment Cores, Developments in Paleoenvironmental Research. Springer.

Arnaud, F., Révillon, S., Debret, M., Revel, M., Chapron, E., Jacob, J., Giguet-Covex, C., Poulenard, I., Magny, M., 2012. Lake Bourget regional erosion patterns reconstruction reveals Holocene NW European Alps soil evolution and paleohy\begin{tabular}{llllll}
\hline drology. Quat. & Sci. & Rev. 51, 81-92. http://dx.doi.org/10.1016/
\end{tabular} j.quascirev.2012.07.025.

Bajard, M., Sabatier, P., David, F., Develle, A.-L., Reyss, J.-L., Fanget, B., Malet, E., Arnaud, D., Augustin, L., Crouzet, C., Poulenard, J., Arnaud, F., 2015. Erosion record in lake La thuile sediments (prealps, France): evidence of montane landscape dynamics throughout the Holocene. Holocene 26 (3), 350-364. http://dx.doi.org/10.1177/0959683615609750, 959683615609750.

Baster, I., Girardclos, S., Pugin, A., Wildi, W., 2003. High-resolution seismic stratigraphy of an Holocene lacustrine delta in western Lake Geneva (Switzerland). In: Lake Systems from the Ice Age to Industrial Time. Birkhäuser Basel, Basel, pp. 11-20.

Beck, C., Manalt, F., Chapron, E., Rensbergen, P.V., Batist, M.D., 1996. Enhanced seismicity in the early post-glacial period: evidence from the post-würm sediments of lake annecy, northwestern Alps. I. Geodyn. 22, 155-171. http:// dx.doi.org/10.1016/0264-3707(96)00001-4.

Berger, C., McArdell, B.W., Schlunegger, F., 2011. Sediment transfer patterns at the Illgraben catchment, Switzerland: implications for the time scales of debris flow activities. Geomorphology 125, 421-432. http://dx.doi.org/10.1016/ j.geomorph.2010.10.019.

Bertrand, S., Charlet, F., Charlier, B., Renson, V., Fagel, N., 2007. Climate variability of southern Chile since the last glacial maximum: a continuous sedimentological record from lago puyehue $\left(40^{\circ} \mathrm{S}\right)$. J. Paleolimnol. 39, 179-195. http://dx.doi.org/ 10.1007/s10933-007-9117-y.

Bloemendal, J., deMenocal, P., 1989. Evidence for a change in the periodicity of tropical climate cycles at $2.4 \mathrm{Myr}$ from whole-core magnetic susceptibility measurements. Nature 342, 897-900. http://dx.doi.org/10.1038/342897a0.

Bøe, A.-G., Dahl, S.O., Lie, Ø., Nesje, A., 2006. Holocene river floods in the upper Glomma catchment, southern Norway: a high-resolution multiproxy record from lacustrine sediments. Holocene 16, 445-455. http://dx.doi.org/10.1191/ 0959683606hl940rp.

Brisset, E., Miramont, C., Guiter, F., Anthony, E.J., Tachikawa, K., Poulenard, J., Arnaud, F., Delhon, C., Meunier, J.-D., Bard, E., Sumera, F., 2013. Non-reversible geosystem destabilisation at 4200 cal. BP: sedimentological, geochemical and botanical markers of soil erosion recorded in a Mediterranean alpine lake. Holocene 23, 1863-1874. http://dx.doi.org/10.1177/0959683613508158.

Brown, A., Toms, P., Carey, C., Rhodes, E., 2013. Geomorphology of the Anthropocene: time-transgressive discontinuities of human-induced alluviation. Anthropocene 1, 3-13. http://dx.doi.org/10.1016/j.ancene.2013.06.002.

Burt, T.P., Allison, R.J. (Eds.), 2010. Sediment Cascades: an Integrated Approach. Wiley, Chichester; Hoboken, NI.

Butzer, K.W., 2005. Environmental history in the Mediterranean world: crossdisciplinary investigation of cause-and-effect for degradation and soil erosion. J. Archaeol. Sci. 32, 1773-1800. http://dx.doi.org/10.1016/j.jas.2005.06.001.

Certini, G., Scalenghe, R., 2011. Anthropogenic soils are the golden spikes for the Anthropocene. Holocene 21, 1269-1274. http://dx.doi.org/10.1177/ 0959683611408454.

Chapman, M.R., Shackleton, N.J., 1998. What level of resolution is attainable in a deep-sea core? Results of a spectrophotometer study. Paleoceanography 13 , 311-315. http://dx.doi.org/10.1029/98PA01067.

Chapron, E., Arnaud, F., Noël, H., Revel, M., Desmet, M., Perdereau, L., 2005. Rhone river flood deposits in lake le Bourget: a proxy for Holocene environmental changes in the NW alps, France. Boreas 34, 404-416. http://dx.doi.org/10.1080/ 03009480500231260.

Chapron, E., Beck, C., Pourchet, M., Deconinck, I.-F., 1999. 1822 earthquake-triggered homogenite in lake le Bourget (NW alps). Terra Nova 11, 86-92. http:/ dx.doi.org/10.1046/j.1365-3121.1999.00230.x.

Chapron, E., Desmet, M., De Putter, T., Loutre, M.F., Beck, C., Deconinck, J.F., 2002. Climatic variability in the northwestern Alps, France, as evidenced by 600 years of terrigenous sedimentation in Lake Le Bourget. Holocene 12,177-185. http:// dx.doi.org/10.1191/0959683602hl520rp.

Costanza, R., Graumlich, L., Steffen, W., Crumley, C., Dearing, J., Hibbard, K., Leemans, R., Redman, C., Schimel, D., 2007. Sustainability or collapse: what can we learn from integrating the history of humans and the rest of nature? AMBIO J. Hum. Environ. 36, 522-527. http://dx.doi.org/10.1579/0044-7447(2007)36 [522:SOCWCW]2.0.CO;2.

Cruise, G.M., Macphail, R.I., Linderholm, J., Maggi, R., Marshall, P.D., 2009. Lago di Bargone, Liguria, N Italy: a reconstruction of Holocene environmental and landuse history. Holocene 19, 987-1003. http://dx.doi.org/10.1177 0959683609343142.

Crutzen, P.J., 2002. Geology of mankind. Nature 415. http://dx.doi.org/10.1038/ 415023a, 23-23.

Czymzik, M., Brauer, A., Dulski, P., Plessen, B., Naumann, R., von Grafenstein, U., Scheffler, R., 2013. Orbital and solar forcing of shifts in Mid- to Late Holocene flood intensity from varved sediments of pre-alpine Lake Ammersee (southern 
Germany). Quat. Sci. Rev. 61, 96-110. http://dx.doi.org/10.1016/ j.quascirev.2012.11.010.

David, F., 2010a. Expansion of green alder (Alnus alnobetula [Ehrh] K. Koch) in the northern French Alps: a palaeoecological point of view. C. R. Biol. 333, 424-428. http://dx.doi.org/10.1016/j.crvi.2010.01.002.

David, F., 2010b. An example of the consequences of human activities on the evolution of subalpine landscapes. Comptes Rendus Palevol 9, 229-235. http:// dx.doi.org/10.1016/j.crpv.2010.06.002.

Davis, B.A.S., Brewer, S., Stevenson, A.C., Guiot, J., 2003. The temperature of Europe during the Holocene reconstructed from pollen data. Quat. Sci. Rev. 22, 1701-1716. http://dx.doi.org/10.1016/S0277-3791(03)00173-2.

Dearing, J.A., 1983. Changing patterns of sediment accumulation in a small lake in Scania, southern Sweden. Hydrobiologia 103, 59-64. http://dx.doi.org/10.1007/ BF00028428.

Dearing, J.A., Braimoh, A.K., Reenberg, A., Turner, B.L., van der Leeuw, S., 2010. Complex land systems: the need for long time perspectives to assess their future. Ecol. Soc. 15, 21.

Dearing, J.A., Håkansson, H., Liedberg-Jönsson, B., Persson, A., Skansjö, S., Widholm, D., El-Daoushy, F., 1987. lake sediments used to quantify the erosional response to land use change in southern Sweden. Oikos 50, 60-78. http:// dx.doi.org/10.2307/3565402.

Dearing, J.A., Jones, R.T., 2003. Coupling temporal and spatial dimensions of global sediment flux through lake and marine sediment records. Glob. Planet. Change 39, 147-168. http://dx.doi.org/10.1016/S0921-8181(03)00022-5.

Dearing, J.A., Morton, R.I., Price, T.W., Foster, I.D.L., 1986. Physics of the earth and planetary interiors Tracing movements of topsoil by magnetic measurements: two case studies. Phys. Earth Planet. Inter 42, 93-104. http://dx.doi.org/10.1016/ S0031-9201(86)80011-5.

Dearing, J., Yuquan, H., Doody, Pippa, James, Peter A., Brauer, Achim, 2001. Preliminary reconstruction of sediment-source linkages for the past $6000 \mathrm{yr}$ at the Petit Lac d'Annecy, France, based on mineral magnetic data. J. Paleolimnol. 25, 245-258.

Debret, M., Chapron, E., Desmet, M., Rolland-Revel, M., Magand, O., Trentesaux, A., Bout-Roumazeille, V., Nomade, J., Arnaud, F. 2010. North western alps Holocene paleohydrology recorded by flooding activity in lake le Bourget, France. Quat. Sci. Rev. 29, 2185-2200. http://dx.doi.org/10.1016/j.quascirev.2010.05.016.

Deline, P., Orombelli, G., 2005. Glacier fluctuations in the western Alps during the Neoglacial, as indicated by the Miage morainic amphitheatre (Mont Blanc massif, Italy). Boreas 34, 456-467. http://dx.doi.org/10.1111/j.15023885.2005.tb01444.x.

Disnar, J.-R., Jacob, J., Morched-Issa, M., Lottier, N., Arnaud, F., 2008. Assessment of peat quality by molecular and bulk geochemical analysis: application to the Holocene record of the Chautagne marsh (Haute Savoie, France). Chem. Geol. 254, 101-112. http://dx.doi.org/10.1016/i.chemgeo.2008.06.004.

Doig, R., 1990. $2300 \mathrm{yr}$ history of seismicity from silting events, in Lake Tadoussac, Charlevoix. Quebec. Geol. 18, 820. http://dx.doi.org/10.1130/0091-7613(1990) 018<0820:YHOSFS $>2.3$. CO:2.

Doyen, E., Bégeot, C., Simonneau, A., Millet, L., Chapron, E., Arnaud, F., Vannière, B., 2016. Land use development and environmental responses since the neolithic around Lake Paladru in the French pre-alps. I. Archaeol. Sci. Rep. 7, 48-59. http://dx.doi.org/10.1016/j.jasrep.2016.03.040.

Doyen, E., Vanniere, B., Berger, J.-F., Arnaud, F., Tachikawa, K., Bard, E., 2013. Landuse changes and environmental dynamics in the upper Rhone valley since Neolithic times inferred from sediments in Lac Moras. Holocene 23, 961-973. http://dx.doi.org/10.1177/0959683612475142.

Fanetti, D., Anselmetti, F.S., Chapron, E., Sturm, M., Vezzoli, L., 2008. Megaturbidite deposits in the Holocene basin fill of lake Como (southern alps, Italy). Palaeogeogr. Palaeoclimatol. Palaeoecol. 259, 323-340. http://dx.doi.org/10.1016/ j.palaeo.2007.10.014

Finckh, P., Kelts, K., Lambert, A., 1984. Seismic stratigraphy and bedrock forms in perialpine lakes. Geol. Soc. Am. Bull. 95, 1118. http://dx.doi.org/10.1130/00167606(1984) 95<1118:SSABFI>2.0.CO;2.

Fiore, J., Girardclos, S., Pugin, A., Gorin, G., Wildi, W., 2011. Würmian deglaciation of western Lake Geneva (Switzerland) based on seismic stratigraphy. Quat. Sci. Rev. 30, 377-393. http://dx.doi.org/10.1016/i.quascirev.2010.11.018.

Foster, G.C., Dearing, J.A., Jones, R.T., Crook, D.S., Siddle, D.J., Harvey, A.M. James, P.A., Appleby, P.G., Thompson, R., Nicholson, J., Loizeau, J.-L., 2003. Meteorological and land use controls on past and present hydro-geomorphic processes in the pre-alpine environment: an integrated lake-catchment study at the Petit Lac d'Annecy, France. Hydrol. Process 17, 3287-3305. http:// dx.doi.org/10.1002/hyp.1387.

Foster, I.D.L., Dearing, J.A., Simpson, A., Carter, A.D., Appleby, P.G., 1985. Lake catchment based studies of erosion and denudation in the merevale catchment, Warwickshire, U.K. Earth Surf. Process. Landf. 10, 45-68. http://dx.doi.org/ 10.1002/esp.3290100108.

Francus, P., Bradley, R.S., Lewis, T., Abbott, M., Retelle, M., Stoner, J.S., 2008. Limnological and sedimentary processes at Sawtooth Lake, Canadian High Arctic, and their influence on varve formation. J. Paleolimnol. 40, 963-985. http://dx.doi.org/10.1007/s10933-008-9210-x.

Gauthier, E., Richard, H., 2009. Bronze age at Lake Bourget (NW alps, France): vegetation, human impact and climatic change. Quat. Int. 200, 111-119. http:// dx.doi.org/10.1016/j.quaint.2008.10.004. Rhythms and Causalities of the Anthropisation Dynamic in Europe between 8500 and 2500 cal BP: Sociocultural and/or Climatic Assumptions.

Giguet-Covex, C., 2015. Histoire de l'agriculture dans les Alpes françaises: un nouveau regard fournit par l'ADN sédimentaire lacustre.

Giguet-Covex, C., Arnaud, F., Enters, D., Poulenard, J., Millet, L., Francus, P., David, F. Rey, P.-J., Wilhelm, B., Delannoy, J.-J., 2012. Frequency and intensity of highaltitude floods over the last 3.5ka in northwestern French Alps (Lake Anterne). Quat. Res. 77, 12-22. http://dx.doi.org/10.1016/j.yqres.2011.11.003.

Giguet-Covex, C., Arnaud, F., Poulenard, J., Disnar, J.-R., Delhon, C., Francus, P. David, F., Enters, D., Rey, P.-I., Delannoy, J.-I., 2011. Changes in erosion patterns during the Holocene in a currently treeless subalpine catchment inferred from lake sediment geochemistry (Lake Anterne, $2063 \mathrm{~m}$ a.s.l., NW French Alps): the role of climate and human activities. Holocene 21, 651-665. http://dx.doi.org 10.1177/0959683610391320.

Giguet-Covex, C., Ficetola, G.F., Walsh, K., Poulenard, J., Bajard, M., Fouinat, L. Sabatier, P., Gielly, L., David, F., Taberlet, P., Arnaud, F., submitted for publication New insights on lake sediment DNA from the catchment: importance of taphonomic and analytical issues on the record quality, Quat. Sci. Rev..

Giguet-Covex, C., Pansu, I., Arnaud, F., Rey, P.-I., Griggo, C., Gielly, L., Domaizon, I., Coissac, E., David, F., Choler, P., Poulenard, J., Taberlet, P., 2014. Long livestock farming history and human landscape shaping revealed by lake sediment DNA. Nat. Commun. 5 http://dx.doi.org/10.1038/ncomms4211.

Gilli, A., Anselmetti, F.S., Glur, L., Wirth, S.B., 2013. lake sediments as archives of recurrence rates and intensities of past flood events. In: SchneuwlyBollschweiler, M., Stoffel, M., Rudolf-Miklau, F. (Eds.), Dating Torrential Processes on Fans and Cones, Advances in Global Change Research. Springer; Netherlands, pp. 225-242.

Gillieson, D., Oldfield, F., Krawiecki, A., 1986. Records of prehistoric soil erosion from rock-shelter sites in Papua New Guinea. Mt. Res. Dev. 6, 315. http://dx.doi.org/ 10.2307/3673372.

Girardclos, S., Fiore, J., Rachoud-Schneider, A.-M., Baster, I., Wildi, W., 2005. PetitLac (western Lake Geneva) environment and climate history from deglaciation to the present: a synthesis. Boreas 34, 417-433. http://dx.doi.org/10.1080/ 03009480500231385.

Glur, L., Stalder, N.F., Wirth, S.B., Gilli, A., Anselmetti, F.S., 2015. Alpine lacustrine varved record reveals summer temperature as main control of glacier fluctuations over the past 2250 years. Holocene 25, 280-287. http://dx.doi.org $10.1177 / 0959683614557572$.

Glur, L., Wirth, S., Büntgen, U., Gilli, A., Haug, G., Schär, C., Beer, J., Anselmetti, F.S., 2013. Frequent floods in the European Alps coincide with cooler periods of the past 2500 years. Sci. Rep.

Goehring, B.M., Schaefer, J.M., Schluechter, C., Lifton, N.A., Finkel, R.C., Jull, A.J.T., Akcar, N., Alley, R.B., 2011. The Rhone Glacier was smaller than today for most of the Holocene. Geology 39, 679-682. http://dx.doi.org/10.1130/G32145.1.

Guyard, H., Chapron, E., St-Onge, G., Anselmetti, F.S., Arnaud, F., Magand, O., Francus, P., Mélières, M.-A., 2007. High-altitude varve records of abrupt environmental changes and mining activity over the last 4000 years in the western French alps (Lake Bramant, grandes rousses massif). Quat. Sci. Rev. 26, 2644-2660. http://dx.doi.org/10.1016/j.quascirev.2007.07.007.

Haug, G.H., 2001. Southward migration of the intertropical convergence zone through the Holocene. Science 293, 1304-1308. http://dx.doi.org/10.1126/ science.1059725.

Hinderer, M., 2001. Late Quaternary denudation of the Alps, valley and lake fillings and modern river loads. Geodin. Acta 14, 231-263. http://dx.doi.org/10.1080 09853111.2001 .11432446$.

Hinderer, M., Kastowski, M., Kamelger, A., Bartolini, C., Schlunegger, F., 2013. River loads and modern denudation of the Alps - A review. Earth-Sci. Rev. 118 11-44. http://dx.doi.org/10.1016/j.earscirev.2013.01.001.

Hjulström, F., 1935. Studies of the Morphological Activity of Rivers as Illustrated by the River Fyris (Thèse de doctorat). Uppsala.

Holzhauser, H., Magny, M.J., Zumbühl, H.J., 2005. Glacier and lake-level variations in west-central Europe over the last 3500 years. Holocene 15, 789-801. http:/ dx.doi.org/10.1191/0959683605hl853ra.

Hormes, A., Müller, B.U., Schlüchter, C., 2001. The Alps with little ice: evidence for eight Holocene phases of reduced glacier extent in the Central Swiss Alps. Holocene 11, 255-265. http://dx.doi.org/10.1191/095968301675275728.

Hornung, J., Pflanz, D., Hechler, A., Beer, A., Hinderer, M., Maisch, M., Bieg, U., 2010. 3-D architecture, depositional patterns and climate triggered sediment fluxes of an alpine alluvial fan (Samedan, Switzerland). Geomorphology 115, 202-214. http://dx.doi.org/10.1016/j.geomorph.2009.09.001.

Hsu, K., Kelts, K.R., 1970. Seismic investigation of lake Zürich. Pt 2: geology. Eclogae Geol. Helv. 525-538.

Hsü, K.J., 1989. Physical Principles of Sedimentology a Readable Textbook for Beginners and Experts. Springer Berlin Heidelberg, Berlin, Heidelberg.

Hsü, K.J., Kelts, K.R. (Eds.), 1984. Quaternary geology of Lake Zurich: an Interdisciplinary Investigation by Deep-lake Drilling, Contributions to Sedimentology. Schweizerbart, Stuttgart.

Ilyashuk, E.A., Koinig, K.A., Heiri, O., Ilyashuk, B.P., Psenner, R., 2011. Holocene temperature variations at a high-altitude site in the Eastern Alps: a chironomid record from Schwarzsee ob Sölden, Austria. Quat. Sci. Rev. 30, 176-191. http:// dx.doi.org/10.1016/j.quascirev.2010.10.008.

Ivy-Ochs, S., Kerschner, H., Maisch, M., Christl, M., Kubik, P.W., Schlüchter, C., 2009 Latest pleistocene and Holocene glacier variations in the European alps. Quat Sci. Rev. 28, 2137-2149. http://dx.doi.org/10.1016/j.quascirev.2009.03.009.

Jacob, J., Disnar, J.-R., Arnaud, F., Chapron, E., Debret, M., Lallier-Vergès, E., Desmet, M., Revel-Rolland, M., 2008a. Millet cultivation history in the French Alps as evidenced by a sedimentary molecule. J. Archaeol. Sci. 35, 814-820. http://dx.doi.org/10.1016/j.jas.2007.06.006. 
Jacob, I., Disnar, I.-R., Arnaud, F., Gauthier, E., Billaud, Y., Chapron, E., Bardoux, G., 2009. Impacts of new agricultural practices on soil erosion during the Bronze Age in the French Prealps. Holocene 19, 241-249. http://dx.doi.org/10.1177/ 0959683608100568.

Jacob, J., Disnar, J.-R., Bardoux, G., 2008b. Carbon isotope evidence for sedimentary miliacin as a tracer of Panicum miliaceum (broomcorn millet) in the sediments of Lake le Bourget (French Alps). Org. Geochem. 39, 1077-1080. http:/ dx.doi.org/10.1016/j.orggeochem.2008.04.003. Advances in Organic Geochemistry 2007 Proceedings of the 23rd International Meeting on Organic Geochemistry.

Jenny, J.-P., Wilhelm, B., Arnaud, F., Sabatier, P., Giguet Covex, C., Mélo, A., Fanget, B. Malet, E., Ployon, E., Perga, M.E., 2014. A 4D sedimentological approach to reconstructing the flood frequency and intensity of the Rhône River (Lake Bourget, NW European Alps). J. Paleolimnol. 51, 469-483. http://dx.doi.org 10.1007/s10933-014-9768-4.

Joannin, S., Magny, M., Peyron, O., Vanniere, B., Galop, D., 2014. Climate and landuse change during the late Holocene at Lake Ledro (southern alps, Italy). Holocene 24, 591-602. http://dx.doi.org/10.1177/0959683614522311.

Joerin, U.E., Nicolussi, K., Fischer, A., Stocker, T.F., Schlüchter, C., 2008. Holocene optimum events inferred from subglacial sediments at tschierva glacier, eastern swiss alps. Quat. Sci. Rev. 27, 337-350. http://dx.doi.org/10.1016/ j.quascirev.2007.10.016.

Joerin, U.E., Stocker, T.F., Schlüchter, C., 2006a. Multicentury glacier fluctuations in the swiss alps during the Holocene. Holocene 16, 697-704. http://dx.doi.org 10.1191/0959683606hl964rp.

Joerin, U.E., Stocker, T.F., Schlüchter, C., 2006b. Multicentury glacier fluctuations in the swiss alps during the Holocene. Holocene 16, 697-704. http://dx.doi.org 10.1191/0959683606hl964rp.

Jones, R.T., Reinhardt, L.J., Dearing, J.A., Crook, D., Chiverrell, R.C., Welsh, K.E. Verges, E., 2013. Detecting climatic signals in an anthropogenically disturbed catchment: the late-Holocene record from the Petit Lac d'Annecy, French Alps. Holocene 23, 1329-1339. http://dx.doi.org/10.1177/0959683613486940.

Jowett, B., 1892. The Dialogues of Plato Translated into English with Analyses and Introductions. Oxford University Press.

Konz, N., Prasuhn, V., Alewell, C., 2012. On the measurement of alpine soil erosion. CATENA 91, 63-71. http://dx.doi.org/10.1016/j.catena.2011.09.010.

Lamoureux, S.F., England, J.H., Sharp, M.J., Bush, A.B.G., 2001. A varve record of increased "Little Ice Age" rainfall associated with volcanic activity, Arctic Archipelago, Canada. Holocene 11, 243-249. http://dx.doi.org/10.1191/ 095968301668776315.

Lauterbach, S., Chapron, E., Brauer, A., Huls, M., Gilli, A., Arnaud, F., Piccin, A., Nomade, J., Desmet, M., von Grafenstein, U., Participants, D, 2012. A sedimentary record of Holocene surface runoff events and earthquake activity from Lake Iseo (Southern Alps, Italy). Holocene 22, 749-760. http://dx.doi.org/ 10.1177/0959683611430340.

Le Roy, M., Nicolussi, K., Deline, P., Astrade, L., Edouard, J.-L., Miramont, C., Arnaud, F., 2015. Calendar-dated glacier variations in the western European Alps during the Neoglacial: the Mer de Glace record, Mont Blanc massif. Quat. Sci. Rev. 108, 1-22. http://dx.doi.org/10.1016/j.quascirev.2014.10.033.

Leemann, A., Niessen, F., 1994. Holocene glacial activity and climatic variations in the Swiss Alps: reconstructing a continuous record from proglacial lake sediments. Holocene 4, 259-268. http://dx.doi.org/10.1177/095968369400400305.

Leroy, M., 2012. Reconstitution des fluctuations glaciaires holocènes dans les Alpes occidentales: apports de la dendrochronologie et de la datation par isotopes cosmogéniques produits in situ. Le Bourget du Lac, Grenoble.

Lespez, L., 2003. Geomorphic responses to long-term land use changes in Eastern Macedonia (Greece). CATENA 51, 181-208. http://dx.doi.org/10.1016/S03418162(02)00164-9.

Lignier, V., 2001. Mécanismes et conditions de l'enregistrement de la sismicité dans des sédiments lacustres. Université de Savoie.

Lister, G.S., Giovanoli, F., Eberli, G., Finckh, P., Finger, W., He, Q., Heim, C., Hsü, K.J., Kelts, K., Peng, C., Sidler, C., Zhao, X., 1983. Late quaternary sediments in Lake Zürich. Switz. Environ. Geol. 5, 191-205. http://dx.doi.org/10.1007/BF02414864.

Lottermoser, B.G., Schütz, U., Boenecke, J., Oberhänsli, R., Zolitschka, B. Negendank, J.F.W., 1997. Natural and anthropogenic influences on the geochemistry of Quaternary lake sediments from Holzmaar. Ger. Environ. Geol. 31, 236-247. http://dx.doi.org/10.1007/s002540050185.

Magny, M., Arnaud, F., Billaud, Y., Marguet, A., 2012. Lake-level fluctuations at Lake Bourget (eastern France) around 4500-3500 cal. a BP and their palaeoclimatic and archaeological implications. J. Quat. Sci. 27, 494-502. http://dx.doi.org/ 10.1002 /jqs.2546

Magny, M., Bossuet, G., Ruffaldi, P., Leroux, A., Mouthon, J., 2011. Orbital imprint on Holocene palaeohydrological variations in west-central Europe as reflected by lake-level changes at Cerin (Jura Mountains, eastern France). J. Quat. Sci. 26, 171-177. http://dx.doi.org/10.1002/jqs.1436.

Magny, M., Vanniere, B., Zanchetta, G., Fouache, E., Touchais, G., Petrika, L., Coussot, C., Walter-Simonnet, A.-V., Arnaud, F., 2009. Possible complexity of the climatic event around 4300-3800 cal. BP in the central and western Mediterranean. Holocene 19, 823-833. http://dx.doi.org/10.1177/0959683609337360.

Manalt, F. Beck, C. Disnar, J.-R., Recourt, P., 2001. Evolution of clay mineral assemblages and organic matter, in the Late glacial-Holocene sedimentary infill of Lake Annecy (northwestern Alps): paleoenvironmental implications. Paleolimnol. 25, 179-192.

Moscariello, A., Schneider, A.M., Filippi, M.L., 1998. Late glacial and early Holocene palaeoenvironmental changes in Geneva Bay (lake Geneva, Switzerland).
Palaeogeogr. Palaeoclimatol. Palaeoecol. 140, 51-73. http://dx.doi.org/10.1016/ S0031-0182(98)00027-3.

Mourier, B., Poulenard, J., Carcaillet, C., Williamson, D., 2010. Soil evolution and subalpine ecosystem changes in the French Alps inferred from geochemical analysis of lacustrine sediments. J. Paleolimnol. 44, 571-587. http://dx.doi.org/ 10.1007/s10933-010-9438-0.

Mourier, B., Poulenard, I., Chauvel, C., Faivre, P., Carcaillet, C., 2008. Distinguishing subalpine soil types using extractible $\mathrm{Al}$ and Fe fractions and REE geochemistry. Geoderma 145, 107-120. http://dx.doi.org/10.1016/i.geoderma.2008.03.001.

Ndiaye, M., Clerc, N., Gorin, G., Girardclos, S., Fiore, I., 2014. Lake neuchâtel (Switzerland) seismic stratigraphic record points to the simultaneous würmian deglaciation of the Rhône glacier and Jura ice cap. Quat. Sci. Rev. 85, 1-19. http://dx.doi.org/10.1016/i.quascirev.2013.11.017.

Nesbitt, H.W., Young, G.M., 1982. Early proterozoic climates and plate motion inferred from major element chemistry of lutites. Nature 715-717.

Nesje, A., Dahl, S.O., Matthews, J.A., Berrisford, M.S., 2001. A 4500 yr record of river floods obtained from a sediment core in Lake Atnsjøen, eastern Norway. J. Paleolimnol. 329-342.

Nicolussi, K., Patzelt, G., 2000. Discovery of early-holocene wood and peat on the forefield of the Pasterze glacier, eastern alps, Austria. Holocene 10, 191-199. http://dx.doi.org/10.1191/095968300666855842.

Noël, H., Garbolino, E., Brauer, A., Lallier-Verges, E., de Beaulieu, J.-L., Disnar, J.-R., 2001. Human impact and soil erosion during the last 5000 yrs as recorded in lacustrine sedimentary organic matter at Lac d'Annecy, the French Alps. J. Paleolimnol. 25, 229-244.

Nomade, J., Chapron, E., Desmet, M., Reyss, J.-L., Arnaud, F., Lignier, V., 2005. Reconstructing historical seismicity from Lake sediments (lake laffrey, western alps, France). Terra Nova 17, 350-357. http://dx.doi.org/10.1111/j.13653121.2005.00620.x.

Oldfield, F., Appleby, P.G., Thompson, R., 1980. Palaeoecological studies of lakes in the highlands of Papua New Guinea: I. The chronology of sedimentation. J. Ecol. 68, 457. http://dx.doi.org/10.2307/2259416.

Oldfield, F., Berthier, F., 2001. The multi-proxy late-Pleistocene and Holocene record from the sediments of the Grand Lac d'Annecy, eastern France. J. Paleolimnol. 25, 133-135. http://dx.doi.org/10.1023/A:1008138618831.

Pansu, J., Giguet-Covex, C., Ficetola, G.F., Gielly, L., Boyer, F., Zinger, L., Arnaud, F., Poulenard, J., Taberlet, P., Choler, P., 2015. Reconstructing long-term human impacts on plant communities: an ecological approach based on lake sediment DNA. Mol. Ecol. 24, 1485-1498. http://dx.doi.org/10.1111/mec.13136.

Passega, R., 1964. Grain size representation by $\mathrm{Cm}$ patterns as a geological tool. J. Sediment. Res. 34

Poirier, C., Chaumillon, E., Arnaud, F., 2011. Siltation of river-influenced coastal environments: respective impact of late Holocene land use and high-frequency climate changes. Mar. Geol. 290, 51-62. http://dx.doi.org/10.1016/ j.margeo.2011.10.008.

Pope, K.O., van Andel, T.H., 1984. Late quaternary alluviation and soil formation in the southern Argolid: its history, causes and archaeological implications. J. Archaeol. Sci. 11, 281-306. http://dx.doi.org/10.1016/0305-4403(84)90012-8.

Poulenard, J., 2011. Des empreintes pédologiques dans les bassins versants et les archives naturelles (Habiliation à diriger des recherches). Université de Savoie.

Revel-Rolland, M., Arnaud, F., Chapron, E., Desmet, M., Givelet, N., Alibert, C., McCulloch, M., 2005. Sr and Nd isotopes as tracers of clastic sources in lake le Bourget sediment (NW alps, France) during the little ice age: palaeohydrology implications. Chem. Geol. 224, 183-200. http://dx.doi.org/10.1016 j.chemgeo.2005.04.014.

Ruddiman, W., 2003. Clim. Change 261-293.

Salvador, P.-G., Berger, J.-F., 2014. The evolution of the rhone river in the Basses Terres basin during the Holocene (alpine foothills, France). Geomorphology 204, 71-85. http://dx.doi.org/10.1016/i.geomorph.2013.07.030.

Schmidt, R., Koinig, K.A., Thompson, R., Kamenik, C., 2002. A multi proxy core study of the last 7000 years of climate and alpine land-use impacts on an Austrian mountain lake (Unterer Landschitzsee, Niedere Tauern). Palaeogeogr. Palaeoclimatol. Palaeoecol. 187, 101-120. http://dx.doi.org/10.1016/S0031-0182(02) 00511-4.

Simonneau, A., Chapron, E., Garcon, M. Winiarski, T., Graz, Y., Chauvel, C. Debret, M., Motelica-Heino, M., Desmet, M., Di Giovanni, C., 2014. Tracking Holocene glacial and high-altitude alpine environments fluctuations from minerogenic and organic markers in proglacial lake sediments (Lake Blanc Huez, Western French Alps). Quat. Sci. Rev. 89, 27-43. http://dx.doi.org/10.1016/ j.quascirev.2014.02.008.

Simonneau, A., Chapron, E., Vannière, B., Wirth, S.B., Gilli, A., Di Giovanni, C., Anselmetti, F.S., Desmet, M., Magny, M., 2013a. Mass-movement and floodinduced deposits in Lake Ledro, southern Alps, Italy: implications for Holocene palaeohydrology and natural hazards. Clim. Past. 9, 825-840. http:// dx.doi.org/10.5194/cp-9-825-2013.

Simonneau, A., Doyen, E., Chapron, E., Millet, L., Vannière, B., Di Giovanni, C., Bossard, N., Tachikawa, K., Bard, E., Albéric, P., Desmet, M., Roux, G. Lajeunesse, P., Berger, J.F., Arnaud, F., 2013b. Holocene land-use evolution and associated soil erosion in the French Prealps inferred from Lake Paladru sediments and archaeological evidences. J. Archaeol. Sci. 40, 1636-1645. http:/ dx.doi.org/10.1016/j.jas.2012.12.002.

Skalak, K.J., Benthem, A.J., Schenk, E.R., Hupp, C.R., Galloway, J.M., Nustad, R.A., Wiche, G.J., 2013. Large dams and alluvial rivers in the Anthropocene: the impacts of the garrison and oahe dams on the upper Missouri river. Anthropocene, geomorphology of the Anthropocene. Underst. Surficial Leg. Past 
Present Hum. Activities 2, 51-64. http://dx.doi.org/10.1016/ j.ancene.2013.10.002.

Støren, E.N., Dahl, S.O., Nesje, A., Paasche, Ø., 2010. Identifying the sedimentary imprint of high-frequency Holocene river floods in lake sediments: development and application of a new method. Quat. Sci. Rev. 29, 3021-3033. http:// dx.doi.org/10.1016/j.quascirev.2010.06.038.

Strasser, M., Monecke, K., Schnellmann, M., Anselmetti, F.S., 2013. Lake sediments as natural seismographs: a compiled record of Late Quaternary earthquakes in Central Switzerland and its implication for Alpine deformation. Sedimentology 60, 319-341. http://dx.doi.org/10.1111/sed.12003.

Swierczynski, T., Lauterbach, S., Dulski, P., Delgado, J., Merz, B., Brauer, A., 2013. Midto late Holocene flood frequency changes in the northeastern Alps as recorded in varved sediments of Lake Mondsee (Upper Austria). Quat. Sci. Rev. 80, 78-90. http://dx.doi.org/10.1016/j.quascirev.2013.08.018.

Syvitski, J.P.M., 2005. Impact of humans on the flux of terrestrial sediment to the global coastal ocean. Science 308, 376-380. http://dx.doi.org/10.1126/ science.1109454.

Syvitski, J.P.M., Kettner, A., 2011. Sediment flux and the Anthropocene. Philos. Trans. R. Soc. Lond. Math. Phys. Eng. Sci. 369, 957-975. http://dx.doi.org/10.1098 rsta.2010.0329.

Trachsel, M., Eggenberger, U., Grosjean, M., Blass, A., Sturm, M., 2008. Mineralogybased quantitative precipitation and temperature reconstructions from annually laminated lake sediments (Swiss Alps) since AD 1580. Geophys. Res. Lett. 35, L13707. http://dx.doi.org/10.1029/2008GL034121.

van Andel, T.H., Zangger, E., Demitrack, A., 1990. Land use and soil erosion in prehistoric and historical Greece. J. Field Archaeol. 17, 379-396. http://dx.doi.org/ 10.1179/009346990791548628.

van Rensbergen, P., de Batist, M., Beck, C., Chapron, E., 1999. High-resolution seismic stratigraphy of glacial to interglacial fill of a deep glacigenic lake: lake Le Bourget, Northwestern Alps, France. Sediment. Geol. 128, 99-129. http:/ dx.doi.org/10.1016/S0037-0738(99)00064-0.

Vannière, B., Magny, M., Joannin, S., Simonneau, A., Wirth, S.B., Hamann, Y., Chapron, E., Gilli, A., Desmet, M., Anselmetti, F.S., 2013. Orbital changes, variation in solar activity and increased anthropogenic activities: controls on the Holocene flood frequency in the Lake Ledro area, Northern Italy. Clim. Past. 9, 1193-1209. http://dx.doi.org/10.5194/cp-9-1193-2013.

Wessels, M., 1998. Natural environmental changes indicated by late glacial and Holocene sediments from lake constance, Germany. Palaeogeogr. Palaeoclimatol. Palaeoecol. 140, 421-432. http://dx.doi.org/10.1016/S0031-0182(98) $00026-1$.

Wilhelm, B., Arnaud, F., Enters, D., Allignol, F., Legaz, A., Magand, O., Révillon, S.,
Giguet-Covex, C., Malet, E., 2012a. Does global warming favour the occurrence of extreme floods in European Alps? First evidences from a NW Alps proglacial lake sediment record. Clim. Change 113, 563-581. http://dx.doi.org/10.1007 s10584-011-0376-2.

Wilhelm, B., Arnaud, F., Sabatier, P., Crouzet, C., Brisset, E., Chaumillon, E., Disnar, J.R., Guiter, F., Malet, E., Reyss, J.-L., Tachikawa, K., Bard, E., Delannoy, J.-J., 2012b. 1400 years of extreme precipitation patterns over the Mediterranean French Alps and possible forcing mechanisms. Quat. Res. 78, 1-12. http://dx.doi.org 10.1016/i.yqres.2012.03.003.

Wilhelm, B., Arnaud, F., Sabatier, P., Magand, O., Chapron, E., Courp, T., Tachikawa, K. Fanget, B., Malet, E., Pignol, C., Bard, E., Delannoy, J.-J., 2013. Palaeoflood activity and climate change over the last 1400 years recorded by lake sediments in the north-west European Alps. J. Quat. Sci. 28, 189-199. http://dx.doi.org/10.1002/ jqs.2609.

Wilhelm, B., Nomade, J., Crouzet, C., Litty, C., Sabatier, P., Belle, S., Rolland, Y. Revel, M., Courboulex, F., Arnaud, F., Anselmetti, F.S., 2016a. Quantified sensitivity of small lake sediments to record historic earthquakes: implications for paleoseismology. J. Geophys. Res. Earth Surf. 121, 2-16. http://dx.doi.org 10.1002/2015JF003644.

Wilhelm, B., Sabatier, P., Arnaud, F., 2015. Is a regional flood signal reproducible from lake sediments? Sedimentology 62, 1103-1117. http://dx.doi.org/10.1111/ sed.12180.

Wilhelm, B., Vogel, H., Crouzet, C., Etienne, D., Anselmetti, F.S., 2016b. Frequency and intensity of palaeofloods at the interface of Atlantic and Mediterranean climate domains. Clim. Past. 12, 299-316. http://dx.doi.org/10.5194/cp-12-2992016.

Wirth, S.B., Gilli, A., Simonneau, A., Ariztegui, D., Vannière, B., Glur, L., Chapron, E., Magny, M., Anselmetti, F.S., 2013a. A 2000 year long seasonal record of floods in the southern European Alps. Geophys. Res. Lett. 40, 4025-4029. http:/ dx.doi.org/10.1002/grl.50741.

Wirth, S.B., Glur, L., Gilli, A., Anselmetti, F.S., 2013b. Holocene flood frequency across the Central Alps - solar forcing and evidence for variations in North Atlantic atmospheric circulation. Quat. Sci. Rev. 80, 112-128. http://dx.doi.org/10.1016 j.quascirev.2013.09.002.

Zalasiewicz, J., Williams, M., Haywood, A., Ellis, M., 2011. The Anthropocene: a new epoch of geological time? Philos. Trans. R. Soc. Lond. Math. Phys. Eng. Sci. 369 835-841. http://dx.doi.org/10.1098/rsta.2010.0339.

Zolitschka, B., Behre, K.-E., Schneider, J., 2003. Human and climatic impact on the environment as derived from colluvial, fluvial and lacustrine archives-examples from the Bronze Age to the Migration period. Ger. Quat. Sci. Rev. 22, 81-100. http://dx.doi.org/10.1016/S0277-3791(02)00182-8. 